\title{
WAKTU DAN TEMPAT KEMUNCULAN HADIS: \\ Suatu Diskursus Kesarjanaan
}

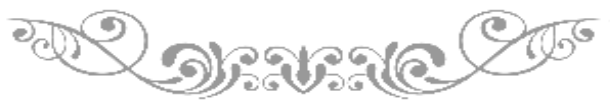

Aceng Abdul Kodir

UIN Sunan Gunung Djati Bandung

Email: aceng.qodir@uinsgd.ac.id

\begin{abstract}
From the very beginning, Hadith came with inherent problems. At least, two aspects always accompany the study of the Prophet's Hadith, namely authenticity and authority. Authenticity has been a subject of study to challenge hadith scholars, from the past until now. The best achievement from study of Hadith authenticity is knowing and discovering the origins of Hadith, both in aspects of time and place. The authority aspect of hadith as a source of Islamic teachings was well resolved by al-Shäfi'i (d. 204) until he received the title nassir al-sunnah. This article intends to introduce the latest trends in the study from origins of Hadith; first, regarding the time, when a hadith appears, second, regarding the place where a hadith was born. To produce a convincing formulation, the author uses the study of regional Hadith (regionalism). In conclusion, regional Hadith studies can answer not only when, but also where a hadith was born and became mainstream in a particular area.
\end{abstract}

Keywords: Dating Hadith, Madrasah of Hadith, Geographical Sanad.

\begin{abstract}
Abstrak
Sejak awal Hadis hadir dengan masalah bawaannya. Paling tidak, dua aspek selalu menyertai kajian Hadis Nabi, yaitu otentisitas dan otoritas. Otentisitas menjadi bahan kajian menantang pengkaji Hadis, sejak dulu hingga kini. Capaian terbaik kajian otentisitas Hadis adalah mengetahui dan menemukan asal-usul (the origins) Hadis, baik aspek waktu maupun tempat. Aspek otoritas Hadis sebagai sumber ajaran Islam diselesaikan dengan baik oleh al-Shāfi ${ }^{` i}$ (w. 204) sehingga ia mendapatkan gelar nășir al-sunnah. Artikel ini bertujuan memperkenalkan tren terbaru studi tentang asal-usul Hadis (origins of hadith); pertama, menyangkut waktu, kapan sebuah Hadis muncul, kedua, terkait tempat di mana sebuah Hadis lahir. Untuk menghasilkan rumusan
\end{abstract}


yang meyakinkan, penulis menggunakan studi Hadis kawasan (regionalism). Kesimpulannya, studi Hadis kawasan bisa menjawab selain kapan, tapi juga di mana sebuah Hadis lahir dan menjadi arus utama pada suatu wilayah tertentu.

Kata Kunci: Dating Hadith, Madrasah Hadis, Sanad Geografis.

\section{PENDAHULUAN}

Sejauh ini pemahaman terhadap Hadis Nabi Muhammad SAW. cenderung ahistoris, Nabi Muhammad sebagai sumber Hadis, diposisikan di luar konteks ruang dan waktu kemanusiaan. Dalam batas-batas tertentu, pengkultusan terhadap sosok Nabi mewujud dalam sikap puritan berlebihan, misalnya termasuk menganggap segala perilaku Nabi dibimbing wahyu. ${ }^{1}$ Bahwa Nabi mendapat bimbingan wahyu merupakan sesuatu yang aksiomatis, tetapi bahwa Nabi juga manusia biasa harus dianggap sebagai kenyataan lain. ${ }^{2}$ Demikian karena, misalnya dalam diskursus kesarjanaan Barat, Nabi Muhammad dianggap sebagai sosok imajinatif belaka, hasil rekonstruksi ulama abad ke-2 dan ke-3 hijriyah, Nabi tidak benar-benar ada sebagai sosok atau personal sejarah, ia hasil imajinasi generasi awal Islam dengan kepentingan yang tidak seutuhnya dapat diterima. ${ }^{3}$

Pada akhirnya, memang harus dibedakan antara memahami Nabi dan memahami Hadis Nabi. Keduanya tidak bisa dianggap sebagai satu wujud dengan tingkat kemiripan yang tinggi. Secara metodologis, misalnya memahami Nabi di antaranya harus melalui Hadis Nabi. ${ }^{4}$ Adapun memahami Hadis Nabi diperlukan seperangkat metodologis-didaktis, sejarah misalnya. ${ }^{5}$ Meski kemudian, sumber-sumber yang digunakan dalam memahami Nabi

${ }^{1}$ Misalnya slogan 'kembali kepada al-Qur'an dan sunnah' dianggap sebagai solusi bagi berbagai problem keislaman dan kemanusiaan. Padahal al-Quran dan Sunnah serangkaian teks yang tidak bisa memberikan makna apa-apa jika pembacanya, tidak memiliki kekayaan perspektif dan pengalaman yang memadai. Akhirnya, Islam meminjam istilah Ulil Abshar Abdala, menjadi bibliotaris (penyembahan pada teks). Lihat, Yudian Wahyudi, "The Slogan 'Back to the Qur' an and the Sunna': A Comparative Study of the Responses of Hasan Hanafi, Muhammad 'Ābid al-Jabiri and Nurcholis Madjid," (Ph.D thesis at The Institute of Islamic Studies McGill University Montreal Canada 2002); Zuhairi Misrawi (ed), Menggugat Pemikiran Anak Muda NU(Jakarta: Kompas, 2004).

2 Gotfried Hagen, "The Imagined and Historical Muhammad," Journal of the American Oriental Society 129, 1 (2009): 97-98.

3 Andreas Görke, Prospects and Limits in the Study of the Historical Muhammad," in Nicolet Boekhoff at al,. The Transmision and Dynamics of the textual Sources of Islam: Essays in Honour of Harald Motzki (Leiden: Brill, 2011), 139.

${ }^{4}$ Jamila Shaukat, "Clasification of Hadith Literature," Islamic Studies Vol. 24, No. 3 (1985): 357-375.

${ }^{5}$ Gregor Schoeler,"Foundation for a New Biography of Muhammad: The Production and Evaluation of the Corpus of the Tradition According to "Urwah ibn al-Zubayr," in Herbert Berg (ed)., Method and Theory in the Study of Islamic Origins (Leiden: Brill, 2003), 21. 
dibedakan oleh para sarjana. Misalnya, apakah melalui Hadis, maghāzí, atau sirah. ${ }^{6}$ Ketiga istilah ini memiliki konteks maksud yang bisa berbeda, mungkin juga sama. Bagaimana memahami Nabi secara baik, ulama abad pertengahan telah menyediakan bahan yang baik untuk itu. ${ }^{7}$ Literatur berbentuk Hadis, maghäzi dan sirah, meski dengan perdebatan sengit, tetap dianggap sebagai sumber yang valid dalam memahami Nabi.

Secara lebih praktikal, literatur berbentuk Hadis, maghäzi dan sïrah berpangkal pada informasi oral, baik dari tabiin, Sahabat junior maupun Sahabat senior. ${ }^{8}$ Demikian karena, diketahui Hadis Nabi tidak seperti alQur'an ditulis pada masa Nabi masih hidup. ${ }^{9}$ Literatur-literatur tersebut secara kronologis sebagian besar lahir pada abad ke-2 dan ke-3 hijriyah. ${ }^{10}$ Bahkan sarjana Barat Joseph Schacht (w.1969), menganggap Hadis misalnya, sebagai proyeksi ke belakang (backward projection) ulama abad ke-2 dan ke3 hijriyah. ${ }^{11}$ Hadis tidak benar-benar mencerminkan tradisi Nabi dan kenabian yang sebenarnya. Dalam artikulasi yang lain, Hadis merupakan perkembangan sosiologis umat Islam awal. ${ }^{12}$

Berpangkal dari logika di atas, validitas dan reliabilitas memahami Nabi Muhammad secara hirarkis, bagaimanapun harus melalui Sahabat. ${ }^{13}$ Tidak ada sumber lain yang bisa dijadikan bahan informasi merekonstruksi sejarah Nabi dan kenabian kecuali melalui Sahabat. Gerakan masif ahli Hadis mengkristal pada akhir abad ke-2 dan ke-3 hijriyah. Itu artinya dilakukan oleh generasi tabiin atba $\bar{a}^{‘}$ tabiin (tabiin senior dan junior). ${ }^{14}$ Tentu saja ulamaulama pada abad ini merekonstruksi sejarah Nabi berdasarkan sumber-sumber atau informasi yang diterima dari seorang Sahabat Nabi di suatu ruang dan masa tertentu. Memang keruwetan memahami sejarah Nabi pada masa tabiin tidak semudah pada masa Sahabat. Jika pada masa Sahabat, hampir para

${ }^{6}$ Muhammad Qasim Zaman, "Maghāzì and Muhaddithūn: Reconsidering the Treatment of Historical Materials in Early Collections of Hadith, "International Journal of Middle East Studies Vol 28, No. 1 (1996) : 1-18.

${ }^{7}$ Fred M. Donner, Narrative of Origins: The Beginnings of Islamic Historical Writing (Princeton: Darwin Press, 1999), 280-290; Jamila Shaukat, "Clasification of Hadith Literature," Islamic Studies Vol. 24. No. 3 (1985).

${ }^{8}$ Jonathan A. C Brown, Hadith: Muhammad's Legacy in the Medieval and Modern World (Oxford: Oneworld, 2009), 18-24.

${ }^{9}$ Michael A.Cook, The Opponents of the Writing of Tradition in Early Islam" Arabica 44 (1997): 437-530.

${ }^{10}$ Andreas Görke, "Prospects and limits in the Study of Muhammad," 138-139.

${ }^{11} \mathrm{Ze}$ 'ev Maghen, "Joseph Schacht and the Origins of Popular Practice," Islamic Law and Society 10, 3 (2003) : 277-287.

${ }^{12}$ Jonathan A.C. Brown, Hadith: Muhammad's Legacy, 205-217.

${ }^{13}$ Kamaruddin Amin, Menguji Kembali Keakuratan Metode Kritik Hadis (Bandung: Mizan, 2009), 4-5.

${ }^{14}$ Scott Cameron Lucas, "The Arts of Hadith Compilation and Criticism: A Study of Emergence of Sunnism in the Third/Ninth Century," (Ph.D Dissertation of Department of Near Eastern Languages and Civilizations Chicago University, 2002), 213. 
Sahabat tidak berpencar atau berdiaspora luas sebagaimana tabiin, tidak juga kepentingan-kepentingan yang ada pada masa Sahabat, serumit dan sekompleks masa tabiin. ${ }^{15}$

Di mana Nabi tinggal, secara otomatis Nabi mewarisi sunnah atau bahan baku Hadis. Di manapun Nabi berada, ia ditemani atau dikelilingi oleh para Sahabat. ${ }^{16}$ Nabi seperti garam, di manapun tinggal dan berada mewarnai ruang dan waktu tertentu. Ruang dan waktu itu dalam bentuknya yang lain terekam atau direkam oleh Sahabat. Dengan begitu, sunnah atau Hadis Nabi secara aktif hanya ada dalam diri Sahabat. ${ }^{17}$ Bahwa kemudian sunnah Nabi menjadi Hadis yang tertulis merupakan metamorfosis dari yang ideal ke dalam lokalitas dan resepsi tiap orang dalam konteks ruang dan waktu. ${ }^{18}$

Dalam memahami Nabi, anggap saja Nabi Muhammad sudah wafat (demikian adanya) kemudian kita, generasi yang hidup pada abad ke-21 hendak mengetahuinya, mula-mula kita melakukan ziarah balik ke belakang, ke masanya yang paling awal. Dating Hadith adalah usaha melakukan penanggalan terhadap Hadis Nabi, kapan dan di mana sebuah Hadis muncul dan disebarkan. ${ }^{19}$ Secara sederhana, asal-usul Hadis dimaknai sebagai penanggalan Hadis. Menanggal Hadis (dating hadith) berarti mengetahui asalusul Hadis baik waktu maupun tempat (ruang dan waktu). ${ }^{20}$

Sebelum ke arah itu, tentang dating hadith, perlu dijelaskan duduk persoalan tema ini berdasarkan kajian terdahulu yang relevan. Studi ini berasal dari tesis beberapa ilmuan Barat dalam kajian Hadis sebelumnya, yaitu G.H.A Juynboll (w. 1935-2010), Joseph Schacht (1902-1969), dan Harald Motzki (lahir 1948). ${ }^{21}$ Ketiganya merupakan ilmuan yang mengkaji asal-usul Hadis (the origins of hadith) yang menghasilkan teori cukup menarik untuk dikaji kemudian.

Seperti dikemukakan di atas, dating hadith berarti mengetahui asalusul Hadis. Ia tidak hanya menyangkut soal waktu, tetapi tempat suatu Hadis

15 Fu'ad Jabali, The Companions of the Prophet: A Study of Geographical Distribution and Political Alignments (Leiden: Brill, 2003).

16 Fatma Kizil, "Fazlur Rahman's Understanding of the Sunnah/Hadith: A Comparison with Joseph Schact's View on Subject," Hadis Tetkikleri Dergisi VI/II (2009): 44-45.

${ }^{17}$ Volkan Yildiran Stodolsky, “ A New Historical Model and Periodization for the Perception of the Sunna of the Prophet and his Companions," (Ph.D Dissertation of Department of Near Eastern Languages and Civilizations, Chicago University, 2012).

18 Adis Dudireja, "Evolution in Canonical Sunni Hadith Body of Literature and Concept of an Authentic Hadith During the Formative Period of Islamic Thought as Based on Recent Western Scholarship,” Arab Law Quarterly 23 (2009): 1-17.

${ }^{19}$ Kamaruddin Amin, Menguji Kembali Keakuratan Metode Kritik Hadis; Harald Motzki, "Dating Muslim Tradition: A Survey," Arabica 52, 2 (2005) : 204-253.

${ }^{20}$ Jonathan A.C. Brown, Hadith: Muhammad's Legacy, 226-227.

${ }^{21}$ Jonathan A.C. Brown, Hadith: Muhammad's Legacy, 240-260. 
diproduksi. ${ }^{22}$ Karena itu, dating hadith berkepentingan mengetahui asal-usul kemunculan Hadis dalam sorotan ruang dan waktu. Dalam kalimat pertanyaan, bisa kita ajukan, misalnya kapan dan di mana sebuah Hadis muncul?

Dalam usaha menanggal Hadis, Juynboll menggunakan istilah common link..$^{23}$ Menggunakan teori isnad ia sampai pada kesimpulan bahwa pencet us Hadis (produsen Hadis) atau common link adalah Tabiin. ${ }^{24}$ Dengan kesimpulannya ini, Juynboll hendak mengatakan asal-usul Hadis muncul pada abad ke-3 hijriyah. Pernyataan ini sekaligus mengamini kesimpulan beberapa sarjana Barat awal sebelum Juynboll..$^{25}$ Kesimpulan ini dihasilkan, sematamata karena ia berpatokan pada sanad (rangkaian periwayat) Hadis dan mengesampingkan analisa terhadap matan (isi atau redaksi) Hadis. ${ }^{26}$

Pasca Juynboll, dating hadith diramaikan oleh Harald Motzki. Ilmuan berkebangsaan Jerman ini menghasilkan teori isnad cum matn. ${ }^{27}$ Sama-sama berkepentingan menanggal Hadis, bedanya dengan Juynboll, Motzki menggunakan isnad dan matn sekaligus sebagai bahan untuk menanggal Hadis. Pendekatan yang sekaligus sebagai bahan menanggal Hadis. Pendekatan yang berbeda dengan Juynboll, menghasilkan kesimpulan yang berbeda pula. Menurut Motzki, asal-usul Hadis secara waktu bisa ditanggal lebih awal 100 tahun ketimbang perhitungan Juynboll. ${ }^{28}$ Jika Juynboll menyebut asal-usul Hadis berasal dari masa tabiin (abad ke-2 dan ke-3 hijriyah), Motzki menyebut Sahabat sebagai asal-usul Hadis (akhir abad pertama hijriyah). ${ }^{29}$

Berdasarkan penelitian Motzki, penulis hendak menguatkan bahwa asal-usul Hadis, baik secara tempat, terutama waktu berasal dari generasi Sahabat. Karena itu, kemudian adalah penting melihat asal-usul Hadis berdasarkan pola hunian Sahabat. Demikian karena, ini ditengarai, pasca Nabi wafat, para Sahabat tidak lagi terkonsentrasi di Madinah, tetapi menyebar ke

22 Term madrasah hadith dianggap sebagai ruang (tempat) hadis muncul dan berkembang. Lihat Muhammad al-Thānī 'Umar Mūsa, al-Madrasah al-Hadithiyyah fí Makkah wa Atharuhā fí al-Hadith wa 'Ulümih min Nash'atihā hattā Nihāyah al-Qarn alThāni al-Hijrī (Riyāẹ: Maktabah Dār al-Minhāj, 1428).

${ }_{23}$ G.H.A Juynboll, Muslim Tradition: Studies in Chronology, Provenance, and Authorship of Early Hadith (Cambridge: Cambridge University Press, 1985), 161.

${ }^{24}$ Jonathan A.C. Brown, Hadith: Muhammad's Legacy, 216.

${ }^{25}$ Seperti Ignaz Goldziher, Wiliam Muir, Joseph Schahct. Jonathan A.C Brown, Hadith: Muhammad's Legacy, 205-206.

${ }^{26}$ Harald Motzki, "Whither Hadith Studies?," in Analysing Muslim Tradition: Studies in Legal, Exegetical and Maghāzi Hadith (Leiden: Bill, 2010): 122-124.

27 Harald Motzki, "Dating Muslim Tradition: A Survey," Arabica (2005): Mohammad Sa ‘ìd Mitwally Ibrāhim al-Rahawān, "Detecting Textual Additions of Reliable Hadith Transmitters," Islamic Studies 49, 3 (2010): 321.

${ }^{28}$ Kamaruddin Amin, Menguji Kembali Keakuratan, ix.

${ }^{29}$ Kamaruddin Amin, Menguji Kembali Keakuratan, 4-5. 
berbagai daerah, baik untuk melakukan penaklukan, maupun penguatan pengajaran keislaman. ${ }^{30}$

\section{PEMBAHASAN}

\section{Proses Terbentuknya Hadis Nabi}

Dalam pengertian praktis, nomenklasi Hadis otomatis merujuk kepada sanad dan matan secara sekaligus, meski secara lumrah lebih utama merujuk kepada matan Hadisnya saja. ${ }^{31}$ Bagaimana sebuah laporan tentang Nabi muncul dalam sejarah intelektual Islam awal? Pertanyaan ini penting dikemukakan sekaligus diarusutamakan agar kita tahu dan mengerti bahwa 'Hadis' sebagai produk kerja intelektual ulama Islam awal lahir tidak dalam ruang kosong dan bebas kepentingan.

Terdapat beberapa orientalis berpendapat, sunnah adalah praktik kaum muslim pada zaman awal. Sebagian kandungan sunnah berasal dari kebiasaan Jahiliyah (pra-Islam) yang kemudian dilestarikan dalam Islam, disebut juga dengan istilah shar'un man qablanā. Sebagian lagi hanya interpretasi para ahli hukum Islam terhadap sunnah yang ada, ditambah unsurunsur yang berasal dari kebudayaan Yahudi, Romawi dan Persia. Ketika gerakan Hadis muncul pada abad ke-3 hijriyah, seluruh sunnah yang ada, dinisbahkan kepada Nabi Muhammad, dan disebut sunnah Nabi. ${ }^{32}$

Fazlur Rahman mengoreksi pandangan orientalis ini dengan menegaskan: sekarang kami akan menunjukkan pertama, bahwa sementara kisah perkembangan sunnah di atas hanya benar sehubungan dengan kandungannya, tapi tidak benar sehubungan dengan konsepnya yang menyatakan sunnah Nabi tetap merupakan konsep yang memiliki validitas dan operatif, sejak awal sejarah Islam hingga kini. Kedua, bahwa kandungan sunnah yang bersumber dari Nabi tidak banyak jumlahnya dan tidak dimaksudkan spesifik secara mutlak. Ketiga, bahwa konsep sunnah sesudah Nabi wafat tidak hanya mencakup sunnah Nabi tapi juga penafsiranpenafsiran terhadap sunnah Nabi tersebut. Keempat, bahwa sunnah dalam pengertian terakhir ini, sama luasnya dengan ijma' yang pada dasarnya

${ }^{30}$ Motivasi perpindahan sahabat dari satu daerah ke daerah lain, lihat Fu'ad Jabali, The Companion of Prophet: A Study of Geographical Distribution and Political Alignments, 94-110.

${ }^{31}$ Hadis setidaknya terdiri dari sanad dan matan. Lihat Muhammad b. Muhammad Abū Shuhbah, al-Wasịt fí 'Ulüm wa-Muștalāh al-Hadith (Kairo: 'Ālam al-Ma'rifat, t.t), 1519.

${ }^{32} \mathrm{Sa}$ 'd b. 'Abdullāh al-Ḥamīd, "Shubuhāt al-Mustashriqīin fì Mafhūm al-Sunnah", Jāmi'ah al-Malak al-Sa'ūd; Noorudheen, "Authenticity of Hadith Literature: With Special Reference to Oriental's View”, ( $P G$ dissertation Darul Huda Islamic University) 15-21; Mohamed Salem al-Shehri, "Western Works and View On Hadith: Beginning, Nature and Impact” Marmara Universitesi Ilahiyat Fakultesi Dergisi. Cilt-Sayi 46 (2014): 208-216. 
merupakan sebuah proses yang semakin meluas secara terus menerus, dan keenam, bahwa setelah gerakan pemurnian Hadis yang besar-besaran, hubungan organis di antara sunnah, ijtihad, dan ijma' menjadi rusak. ${ }^{33}$

Menurut Fazlur Rahman, tahapan-tahapan pembentukan Hadis adalah sebagai berikut: ${ }^{34}$

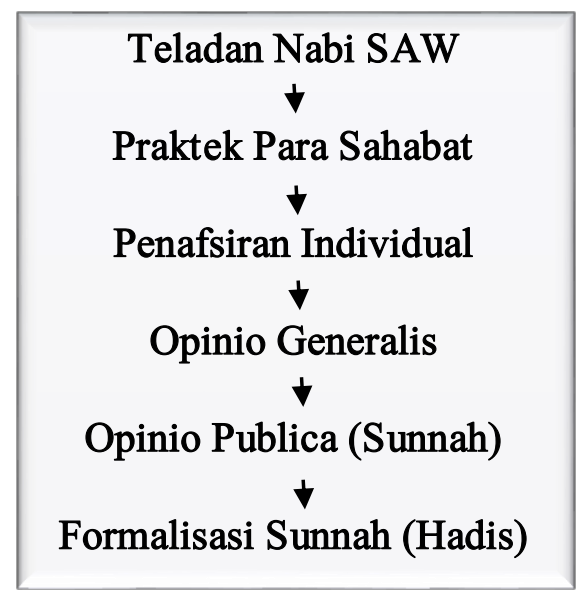

Tabel 1.

Proses Terbentuknya Hadis Nabi

Berdasarkan skema di atas, para Sahabat Nabi memperhatikan segala perilaku, perkataan dan perbuatan Nabi SAW., sebagai sebuah teladan imperatif. Demikian karena terdapat garansi dari Allah Swt. di dalam alQur' an bahwa Nabi selalu berada dalam bimbingan wahyu, ${ }^{35}$ di ayat yang lain Allah memerintahkan umat Islam untuk mengikutinya. ${ }^{36}$ Para Sahabat berusaha mempraktikkan teladan dari Nabi itu dalam kehidupan sehari-hari dengan penuh penghayatan. Hal berbeda terjadi setelah Nabi wafat, penafsiran-penafsiran individual terhadap teladan Nabi berkembang sedemikian rupa. Ada kalanya sebagian Sahabat memandang perilaku tertentu dari Nabi sebagai sunnah, tapi pada saat yang sama Sahabat yang lain tidak menganggapnya sunnah yang memiliki visi mengikat. Menurut Jalaludin Rakhmat, dalam free market of ideas, pada daerah tertentu seperti Madinah dan Küfah berkembang sunnah yang umumnya disepakati para ulama di daerah tersebut. Ada sunnah Madinah, ada sunnah Küfah. Secara berangsurangsur, pada daerah kekuasaan kaum muslim, berkembang secara demokratis

33 Jalaludin Rakhmat, Al-Musthafa Manusia Pilihan yang Disucikan (Bandung: Simbiosa Rekatama, 2008), 33.

${ }^{34}$ Suryadi, "Dari Living Sunnah ke Living Hadis" dalam Metodologi Penelitian Living Qur'an dan Hadis (ed) Sahiron Syamsuddin (Yogyakarta: Teras \& TH Press, 2007), 92.

${ }^{35}$ Q.S al-Aḥzāb [33]: 21.

${ }^{36}$ Q.S al-Hashr [59]: 7. 
sunnah yang disepakati (amr al-mujtama' 'alayh). Karena itu, sunnah tidak lain dari pada opinion publica. Ketika timbul gerakan Hadis pada paruh kedua abad ke-2 hijriyah, sunnah yang sudah disepakati kebanyakan orang ini, diekspresikan dalam bentuk Hadis. Hadis adalah verbalisasi sunnah. ${ }^{37}$ Sayangnya, menurut Fazlur Rahman, formalisasi sunnah ke dalam Hadis ini, telah memasung proses kreatif sunnah dan menjerat para ulama Islam pada rumus-rumus yang kaku. ${ }^{38}$

Barangkali, banyak orang akan kaget membaca pandangan Fazlur Rahman tentang Hadis, seperti dikutipkan oleh Jalaludin Rakhmat di bawah ini:

"Berulang kali telah kami katakan -mungkin sampai membosankan sebagian
pembaca- bahwa walaupun landasan yang utama adalah teladan Nabi, Hadis
merupakan hasil karya dari generasi-generasi muslim. Hadis adalah keseluruhan
aphorisme yang diformulasikan dan dikemukakan seolah-olah dari Nabi, oleh kaum
muslim sendiri; walaupun secara historis tidak terlepas dari Nabi. Sifatnya yang
aphoristik menunjukkan bahwa Hadis tersebut tidak bersifat historis. Secara lebih
tepat Hadis adalah komentar yang monumental mengenai Nabi oleh umat muslim di
masa lampau."

Melalui kajian sejarah, Joseph Schacht menyebutkan bahwa kata sunnah yang sering dikutip ulama pada abad ke-2 dan ke-3 hijriyah, bukanlah terutama merujuk kepada sunnah Nabi. Menurutnya kata sunnah bermakna perbuatan orang-orang terdahulu. Kata ini sudah terbiasa digunakan oleh orang Arab pra-Islam. ${ }^{39}$ Bahkan, kata ini merujuk kepada 'kebiasaan orang Arab' bisa ditemukan dalam al-Qur'an. ${ }^{40}$

Penggunaan kata sunnah juga merujuk kepada kebiasaan para khalifah. Pasca Nabi wafat, menurut Schacht, Islam mulai menyebar ke berbagai daerah di luar jazirah Arab. Sebagai konsekuensinya, dimungkinkan pertemuan antara Islam dan kultur setempat di daerah taklukan. Dalam hal ini, Schacht menyebut sunnah sebagai masa lalu (precedent), cara hidup (way of life), adalah jelas bahwa ide sunnah sebagai petunjuk prinsipil yang diadopsi dari masyarakat Islam, setelah Nabi wafat bisa berarti sunnah al-khulafä' alrāshidūn. Dengan argumentasi ini, Schacht berkesimpulan bahwa sunnah

37 Fatma Kizil, "Fazlur Rahman's Understanding of the Sunnah/hadith: A Compariosn with Joseph Schacht's View on the Subject" Hadis Tetkiklerri Dergisi VI, 2 (2008): 39 .

38 Jalaludin Rakhmat, Al-Mushthafa: Manusia Pilihan yang Disucikan (Bandung: Simbiosa Rekatama, 2008), 34.

${ }^{39}$ Akh. Minhaji, “Joseph Schacht's Contribution to the Study of Islamic Law”, (MA Thesis Institut of Islamic Studies McGill University Canada), 29; Jeanete Wakin, "Remembering Joseph Schacht (1902-1906)" Ocassional Publication 4 (2003): 35.

${ }^{40}$ Lihat al-Baqarah [2]: 170; al-Zukhruf [43]: 21-24. Kajian lebih lanjut tentang konsep 'sunnah', lihat Ahmad Hasan, "Sunnah as Source of Fiqh", Islamic Studies 39 (2000): 3-6. 
yang dipahami masyarakat muslim bukanlah sunnah Nabi. ${ }^{41}$ Doktrin keagamaan yang ada di masing-masing kota, seperti Küfah, Bașrah, Mekkah dan Madinah memiliki kekuatan hukum tersendiri. ${ }^{42}$ Sumber sunnah bukanlah Nabi Muhammad, akan tetapi living tradition yang ada di beberapa kota besar Islam tadi. Yang paling bertanggung jawab dalam 'islamisasi' atau legalisasi living tradition adalah para ahli hukum ( $q \bar{a}$ ại $i)$ yang ada di masing-masing kota tersebut. ${ }^{43}$

Setelah kaum muslim awal secara berangsur-angsur sepakat menerima sunnah, mereka menisbahkan itu kepada Nabi. Kemudian mereka merumuskan sunnah itu dalam bentuk verbal. Inilah yang disebut Hadis. Bila sunnah adalah proses kreatif yang terus menerus, Hadis adalah pembakuan yang kaku. Ketika gerakan Hadis unggul, ijma' (opinio publica) dan ijtihad (yang merupakan proses interpretasi umat terhadap Islam) menjadi tersisihkan. $^{44}$

MM Azami menolak pandangan orientalis tentang pengertian sunnah itu, baik Goldziher, Margoliouth maupun Schahct. Menurut Azami, tuduhantuduhan itu sangat bertolak belakang dengan keterangan-keterangan yang terdapat di dalam naskah-naskah yang ada, di mana satu sama lain saling mendukung dan menafsiri. Apalagi ucapan Ibn 'Umar, "Manakah yang berhak diikuti, sunnah Rasulullah atau sunnah 'Umar", tampaknya merupakan suatu penegasan terhadap adanya perbedaan pengertian antara dua istilah itu, di mana apabila terjadi perbedaan Sunnah Rasulullah yang wajib diikuti. Dengan demikian jelaslah bahwa sunnah yang wajib diikuti adalah sunnah Nabi SAW. Menurut Azami, jika tradisi atau adat istiadat diartikan sebagai sunnah, maka apa maksud ucapan Ibn 'Umar tersebut?. Kata sunnah secara etimologis berarti tata cara, tradisi dan perilaku hidup, baik yang terpuji maupun tidak. Pengertian etimologi ini sudah dipakai dalam Islam. Pengertian ini kemudian diartikan secara khusus untuk tata cara Nabi SAW. Sedang pengertian yang pertaa tetap dipakai dalam arti sempit. Di sisi lain kata sunnah itu sama sekali bukan istilah animis (jahiliyah), sementara umat Islam juga tidak pernah menggunakannya untuk arti kebiasaan masyarakat. ${ }^{45}$

Bagi beberapa orang, riwayat tentang para Sahabat masih dapat dianggap Hadis, sehingga definisi Hadis sekarang ialah apa saja yang

\footnotetext{
${ }^{41}$ Joseph Schacht, The Origins of Muhammadan Jurisprudence (Oxford: Clarendon, 1959), 80.

42 Jeanete Wakin, "Remembering Joseph Schacht (1902-1906)", 23.

${ }^{43}$ Joseph Schacht, Introduction to Islamic Law (Oxford: Clarendon Paperback, 1964) 7-8.

${ }^{44}$ Lihat penjelasan lebih lanjut Fatma Kizil, "Fazlur Rahman's Understanding of the Sunnah /hadith: A Comparison with Joseph Schacht's View on the Subject", Hadis Tetkileri Dergisi, 38-44.

${ }^{45}$ MM Azami, Hadis nabawi dan Sejarah Kodifikasinya. Terjemah Ali Mustafa Ya'qub (Jakarta: Pustaka, Firdaus, 2009), 25-26.
} 
disandarkan (dinisbahkan) kepada Nabi berupa ucapan, perbuatan, ketetapan atau sifat fisik atau akhlak atau apa saja yang dinisbahkan kepada Sahabat. Namun ahli Hadis bahkan menyebut riwayat para ulama di luar para Sahabat juga sebagai Hadis. Riwayat tentang para Tabiin yakni generasi yang berguru kepada para Sahabat disebut Hadis maqtū'. Dalam Saḥịh Bukhāri, misalnya terdapat Hadis yang berbunyi "Iman itu perkataan dan perbuatan, bertambah dan berkurang." ${ }^{6}$ Ini bukan sabda Nabi. Menurut Bukhārī, ini adalah ucapan para ulama di berbagai negeri. Bukhāri menyebutkan ucapan Rabi' ah al-Ra'y: là yanbaghỉ li-ahad 'indahu shai'un min al-'ilm an yud̦i' a nafsah. ${ }^{47}$

Berdasarkan penjelasan di atas, dapat dipahami bahwa definisi Hadis mengalami perluasan dan perkembangan, mulanya adalah laporan tentang Nabi menjadi laporan tentang Sahabat dan juga Tabi'in. Perluasan definisi ini merupakan usaha untuk menyelamatkan sunnah Nabi secara akademis-ilmiah, maksudnya konsep ini dipergunakan untuk mengukuhkan bahwa tradisi kenabian atau al-sunnah al-nabawiyyah sebagai bahan baku Hadis adalah sesuatu yang ditransmisikan dari satu generasi kepada generasi berikutnya, sebelum akhirnya ia diformalisasi menjadi Hadis. Dalam kerangka ini kita memahami Hadis yang menyatakan bahwa sebaik-baik masa adalah masa Nabi, Sahabat dan Tabi'in. ${ }^{48}$

Menurut Jalaludin Rakhmat, salah satu contohnya adalah Hadis untuk menolak tradisi slametan (tahlilan) pada kematian. Hadis itu berbunyi, "Kami menganggap berkumpul pada ahli mayit dan menyediakan makanan sesudah penguburannya termasuk meratap." Hadis ini merupakan ucapan "Abdullāh al-Bajali, bukan ucapan Nabi. ${ }^{49}$ Demikian pula, kebiasaan melakukan adzan awal pada shalat Jum'at di kalangan ulama tradisional, didasarkan kepada Hadis yang menceritakan perilaku orang Islam di zaman 'Uthmān b. 'Affān (w. 35). Ucapan al-salät-u khair-un min al-naum dalam adzan Subuh adalah tambahan yang dilakukan atas perintah 'Umar b. al-Khațāāb.

Para ahli Hadis dan banyak di antara kita menyamakan Hadis dengan sunnah. Ahli Ușūl Fiqh mendefinisikan sunnah sebagai apa saja yang keluar dari Nabi, selain al-Qur'an, berupa ucapan, perbuatan dan taqri $\bar{r}$, yang tepat untuk dijadikan dalil hukum syara'. ${ }^{50}$ Jadi menurut ulama ushul fiqh, tidak semua Hadis mengandung sunnah. Imam Ahmad pernah diriwayatkan

${ }^{46}$ Șahịh Bukhārī, [kitāb al-Īmān]

${ }^{47}$ Imam Bukhāri memasukkan riwayat ini di dalam kitab Sahịh [kitāb al-'ilm, bāb raf' al-'ilm wa zuhūr al-jahl]. Lihat Ḥamīd Qaufí, muḥạạarāt li al-țalabat al-sanah al-thāniyah qism al-kitāb wa al-sunnah. 21

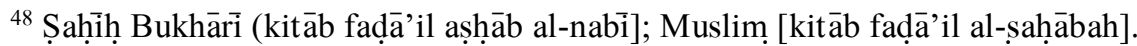

49 Jalaludin Rakhmat, al-Musthafa, 33; Al-Shawkānī, Nail al-Awtār Sharh min Asrār Muntaqā al-Akhbār (Kairo: Dār ibn al-Jauzī, 1427), 4: 148.

50 Muntașir Nāfidh Muhammad Hamidān, "Al-Sunnah baina al-Tashrī' waManhajiyat al-Tahsrìi " (Risālah al-Mājistīir, Kuliyyat Dirāāat al-'Ulya Palestina, 2006) 18. 
berkata, "Dalam Hadis ini ada lima sunnah, fi hadha al-hadith khams alsunnah." ${ }^{1}$ Tidak semua ulama setuju dengan pernyataan Ahmad b. Hanbal ini. Mungki saja buat sebagaian di antara mereka, dalam Hadis hanya ada tiga sunnah. Masalahnya sekarang: Kapan perkataan, perbuatan dan taqrir nabi SAW. itu tepat desbut sunnah, juga siapa yang otoritatif mengatakannya?

Seandainya seorang Sahabat berkata, "Aku mendengar Rasulullah batuk tiga kali setelah takbïrat al-ihrām, dapatkah kita menetapkan itu sebagai perilaku Nabi yang mengandung sunnah. Dalam Hadis itu sebagai sunnah? Kita secara apriori akan menjawab tidak, karena perbuatan Nabi itu hanya kebetulan saja dan tidak mempunyai implikasi hukum, batuk tidak bernilai syar' $i$, ia hanya merupakan tabiat kemanusiaan seseorang.

Tetapi, menurut Jalaludin Rakhmat bagaimana pendapat kita bila Wā'il b. Hujr melaporkan apa yang disaksikannya ketika Nabi duduk tashahhud, "Aku melihat Nabi menggerakkan telunjuknya sambil berdoa?"52 Tidakkah kita akan menyimpulkan bahwa gerakan telunjuk itu sama dengan batuk -yang hanya secara kebetulan tidak mempunyai implikasi hukum. Bukankah Ibn al-Zubayr (w. 94) melihat Nabi memberi isyarat dengan telunjuknya tapi tidak menggerakkannya?"53

Fazlur Rahman dalam Membuka Pintu Ijtihad, menegaskan adanya unsur penafsiran manusia dalam sunnah. Sunnah adalah perumusan para ulama mengenai kandungan Hadis. Ketika terjadi perbedaan paham, maka yang disebut sunnah adalah pendapat umum, sehingga pada awalnya sunnah sama dengan ijma'. Karena sunnah adalah hasil penafsiran, nilai sunnah tentu saja tidak bersifat mutlak seperti al-Qur' an. ${ }^{54}$

Pernyataan Fazlur Rahman ini, bagi kebanyakan orang sangat mengejutkan. Bukanlah selama ini yang dianggap benar secara mutlak adalah al-Quran dan sunnah? Patut dicatat bahwa kesimpulan Fazlur Rahman itu didasarkan pada sunnah dalam pengertian sunnah Rasulullah. Dengan latar belakang uraian sebelumnya, kita menemukan juga adanya sunnah Sahabat, bahkan sunnah para tabiin. ${ }^{55}$

\section{Waktu Sebagai Parameter Asal-Usul Hadis}

Setidaknya, beberapa kajian kekinian terkait asal-usul (penanggalan) Hadis Nabi dapat diklasifikasikan menjadi empat kategori. Pertama, penanggalan yang didasarkan pada matan Hadis; kedua, penanggalan didasarkan pada ketersediaan Hadis dalam kitab kanonik, ketiga, penanggalan

${ }^{51}$ Adonis, Arkeologi Sejarah Pemikiran Arab Islam (Yogyakarta: LKiS, 2011), 1

52 Al-Nasā'ì, Sunan al-Nasa'ī dalam [kitāb al-iftitāh] (Beirut: Dār al-Kutub al'Ilmiyyah, t.th), 1: 126-127.

${ }^{53}$ Al-Shawkānī, Nail al-Awtār: 2: 318.

${ }^{54}$ Fazlur Rahman, Membuka Pintu Ijtihad (Bandung: Pustaka, 1983), 119.

55 Jalaludin Rakhmat, Misteri Wasiat Nabi, Asal-usul Sunah Sahabat: Studi Historiografi atas Tarikh Tasyri' (Bandung: Misykat, 2015), 41. 
didasarkan pada analisa tehadap sanad, dan keempat, penanggalan dengan memadukan antara sanad dan matan Hadis (isnad cum matn analysis). Keempat model penelitian itu menghasilkan kesimpulan masing-masing kapan sebuah Hadis muncul.

Ignaz Goldziher (w. 1921), sarjana kelahiran Hungaria merupakan salah satu sarjana yang melakukan kajian terhadap asal-usul Hadis Nabi berdasarkan penelitian terhadap redaksi atau matan Hadis. Kesimpulan dia terkait asal-usul Hadis baik ditujukan kepada Hadis secara umum maupun kepada bagian-bagian Hadis tertentu. Menaruh kepercayaan tinggi terhadap mazhab sejarah Jerman, Goldziher mendekati teks (matan) Hadis dan juga sumber kesejarahan Islam lainnya dengan menaruh curiga. Tidak pelak lagi ia digolongkan sebagai sarjana Barat yang skeptis terhadap sumber kesejarahan Islam awal. Fakta bahwa tidak ditemukannya dokumen historis tertulis pada masa Nabi hidup, dan bahwa ia ditransmisikan secara oral pasca Nabi wafat, menurutnya sumber kesejarahan Islam awal itu lebih mudah untuk dimanipulasi dan dipalsukan. ${ }^{56}$

Prinsip dasar yang digunakan Goldziher untuk mengetahui asal-usul Hadis adalah anggapannya bahwa sebagian besar koleksi kanonik Hadis berasal dari perkembangan keagamaan, perkembangan sejarah dan sosial masyarakat Islam pada paruh pertama abad ke-2 hijriyah, refleksi dan usaha dari masyarakat Islam awal membangun komunitasnya. ${ }^{57}$ Ia menolak sebagian besar Hadis terkait Nabi dan Sahabatnya sebagai sumber kesejarahan, meski ia tidak seutuhnya menolak menggunakan sumber itu dalam memahami sejaran Islam awal. ${ }^{58}$

Dari mana Goldziher sampai pada kesimpulan-kesimpulan demikian itu, tesis itu lahir, sama sekali didasarkan kepada beberapa matan Hadis yang sangat terbatas yang ia kumpulkan. Berikut ini merupakan landasan yang digunakan Goldziher untuk sampai pada kesimpulan bahwa Hadis tidak berasal dari Nabi, tapi produk pemalsuan generasi belakangan pasca Nabi wafat.

Pertama, perselisihan politik dan perdebatan keagamaan dalam komunitas Islam awal. Menurutnya ada empat motivasi mengapa terjadi pemalsuan tehadap Hadis Nabi: agenda politik; agenda hukum; agenda sektarian dan agenda komunal. ${ }^{59}$ Dari keempat faktor itu, ia meyakini agenda politik sebagai faktor yang utama, terutama dilakukan oleh dinasti Umayyah. Harus diakui, bagaimanapun Umayyah merupakan dinasti sekuler, ia

${ }^{56}$ Jonathan AC. Brown, Hadith: Muhammad's Legacy in the Medieval and Modern World (Oxford: Oneworld, 2015), 205.

${ }^{57}$ Harald Motzki, "Dating Hadith: A Surey," Arabica volume 52, issue 2 (2005): 206.

${ }^{58}$ Harald Motzki, "Dating Hadith: A Surey”, 207.

${ }^{59}$ Jonathan AC. Brown, Hadith: Muhammad's Legacy, 206. 
membutuhkan legitimasi dan otorisasi agar bisa lebih saleh, untuk menciptakan dunia yang religius ia membutuhkan ketersambungan dengan Nabi dan tentu saja khalifah yang empat. Menghadapi ini, para pemuka agama tidak tinggal diam, mereka diminta untuk memalsukan (membuat) Hadis dan disandarkan kepada generasi atau otoritas yang lebih awal. Goldziher berani mengatakan bahwa ada banyak Hadis disebutkan diproyeksikan kepada Nabi atau kepada para Sahabat, secara masif terjadi selama paruh kedua abad pertama hijriyah. ${ }^{60}$ Sebagai contoh, selama Perang Sipil kedua (680-92), ketika musuh dinasti Umayyah, yaitu 'Abdullāh b. al-Zubayr (w. 73/692) mengontrol dan menguasai Mekkah serta rute perjalanan Ibadah Haji, dinasti Umayyah menyebarkan Hadis agar seorang muslim tidak meninggalkan kampung halaman kecuali kepada tiga masjid, yaitu Mesjid al-Haram di Mekkah, Mesjid Nabawi di Madinah dan Mesjid al-Aqsha di Palestina. ${ }^{61}$ Menurutnya, Hadis ini berusaha memalingkan atau memberikan pilihan alternatif bagi para jama' ah Haji untuk mendatangi Palestina, saat itu kota ini berada di bawah kekuasaannya. ${ }^{62}$

Kedua, Hadis lainnya muncul ketika peralihan kekuasaan dari dinasti Umayyah kepada dinasti Abbasiyah pada abad ke-2 hijiryah.

Ketiga, selama paruh kedua abad ke-2 hijriyah ada banyak Hadis bermunculan di antara ahli hukum lama (ahl al-ra'y) dan ulama yang piawai berargumen berdasarkan Hadis (aṣhāb al-ḥadith). Bagi kelompok yang kedua, sebuah hukum harus didasarkan pada contoh dari Nabi dan Sahabatnya, bahkan jikapun tidak ditemukan suatu Hadis, mereka membuatnya. Kelompok pertama, pada saat yang sama menjawab tantangan itu dengan mencari Hadis yang mendukung pandangannya bahkan membuat Hadis yang dikira cocok.

Keempat, ada banyak Hadis muncul atau menyimpang berasal dari pertentangan politik dan pertentangan keagamaan di antara komunitas Islam awal antara yang mempertahankan status quo maupun yang bertindak sebagai oposisi. Suatu kelompok membuat Hadis untuk melawan pemberontakan atau untuk melawan pemerintah atau klaim sebagai berasal dari suku Nabi di hadapan khalifah. Rivalitas di antara suku, ikatan primordial atau lingkaran keulamaan merupakan bagian sebab-sebab munculnya Hadis palsu.

Goldziher mencontohkan sebuah anekdot, seorang ulama (ahli hukum/qāọi) khalifah al-Mahdi (w. 170) menambah kata aw janāḥ kepada suatu Hadis agar permainan perlombaan balapan burung merpati diperbolehkan, sesuatu yang disukai khalifah, sebaliknya ulama ortodoks menganggap itu sesuatu yang menjijikan. Terkait pemalsuan Hadis dan

${ }^{60}$ Jonathan AC. Brown, Hadith: Muhammad's Legacy, 207.

${ }^{61}$ Șaḥih Bukhārī, [kitāb fạ̣l al-ṣalāt fî Masjid Makkata wa al-Madinah]; Șahịh Muslim, [kitāb al-ḥajj].

62 Jonathan AC. Brown, Hadith: Muhammad's Legacy, 206. 
dinasti Umayyah, ia mengatakan bahwa mereka, dalam hal ini dinasti Umayyah mendukung dan bahkan mensponsori pengumpulan awal Hadis secara umum. ${ }^{63}$

Goldziher menggunakan prinsip anakronisme dan analogi untuk mendeteksi sebuah Hadis. Hadis yang kelihatannya terkait suatu konflik dan muncul hanya setelah Nabi wafat, dipastikan ia merupakan sebuah propaganda, diciptakan oleh pihak-pihak yang terkait dalam konflik, bukan kata-kata aktual dari Nabi. Maka, konsekuensinya isi banyak Hadis tidak saja bahwa ia dipalsukan, tapi juga kapan dipalsukan dan oleh siapa dipalsukan. Dengan itu, Goldziher berkesimpulan Hadis bukanlah merupakan peninggalan Nabi tapi merupakan refleksi langsung dari aspirasi masyarakat muslim awal. ${ }^{64}$ Kesimpulan Goldziher di atas, bagaimanapun, sama sekali didasarkan semata terhadap analisa mat an Hadis. Analisis terhadap matan Hadis bisa dan bahkan adakalanya membantu dalam melakukan penanggalan terhadap suatu Hadis. Tapi tentu saja baik jika dikombinasikan dengan metode lainnya.

Menanggal Hadis berdasarkan kemunculan suatu Hadis dalam suatu kitab kanonik dilakukan oleh Joseph Schacht (w. 1902-1969 M). Melalui teori e silentio ia menyatakan bahwa cara terbaik untuk membuktikan bahwa suatu Hadis tidak ada dalam suatu masa tertentu adalah dengan menunjukkan bahwa ia tidak digunakan sebagai dalil hukum dalam suatu diskusi sebagai referensi yaitu jika ia memang ada. ${ }^{65}$ Teori ini secara meyakinkan kemudian digunakan oleh G.H.A Juynboll (w. 1935-2010), dalam menanggal Hadis man kadhdhaba 'alayya ... yang terkenal itu. ${ }^{66}$

Ringkasan kesimpulan Juynboll terkait Hadis itu demikian. Hadis man kadhdhaba 'alayya tidak muncul di Hijāz dan Mesir dalam koleksi Hadis sebelum tahun 180 hijriyah, karena kitab Jāmi' karya 'Abdullāh b. Wahb (w. 197/813) dan Muwatta’ karya Mālik b. Anas (w. 179/795) tidak merekam Hadis ini. Hadis ini pertama kali lahir di Hijāz pada karya al-Shāfi ${ }^{`} \bar{i}$ (w. 204/820) dan al-Ḥumaydi (w. 219/820). 'Abdul 'Azīz b. Muhammad alDarāwardi (w. 187/803) yang muncul di beberapa Hadis Shāfi $\bar{i}$, juga merupakan sumber Mālik b. Anas, sekaligus kunci seseorang yang menyebarluaskan Hadis di Hijāz. Menurut Juynboll, seharusnya Mālik mendengar riwayat dari al-Daräwardi, faktanya tidak demikian. ${ }^{67}$

${ }^{63}$ Harald Motzki, "Dating Muslim Tradition, 206.

${ }^{64}$ Jonathan AC. Brown, Hadith: Muhammad's Legacy, 205.

65 Joseph Schacht, The Origins of Muhammadan Jurisprudence (Oxford: The Clarendon Press, 1975), 140.

${ }^{66}$ Bekir Kuzudisli, "Hadith of Man Kadhaba 'alayya and Argumentum e silentio". Hadith tetkileri Dergisi (TTD).

${ }^{67}$ Lihat Nur Mahmudah, "Pemikiran G. H. A Juynboll tentang Hadis," Mutawatir: Jurnal Keilmuan Tafsir-Hadis Volume 3, Nomor 1 (Juni 2013): 114. 
Hadis ini nampaknya ditemukan di Irak, tepatnya di Musnad alȚayālisī (w. 204/819) sebagai kompilasi Hadis pertama di Irak. Investigasi Juynboll terhadap koleksi kitab Hadis Hijāa , Irak dan Mesir, ia sampai pada kesimpulan bukti bahwa ahli Hadis Sunni di Irak berkembang pada paruh kedua abad kedua hijriyah. ${ }^{68}$ Berikutnya Juynboll mengkomparasikan sanad Hadis ini dengan riwayat Ibn al-Jauzi (w. 597/1201) dalam pembukaan kitab al-Mawd $\bar{u}^{\prime} \bar{a} t$ dengan sembilan kitab kanonik. Hasilnya mencengangkan, sebanyak tiga puluh jalur sanad tidak ditemukan dalam sembilan kitab kanonik. Hadis ini harus dianggap sebagai dipalsukan pada abad ke-4 hijriyah. ${ }^{69}$

Penanggalan Hadis berikutnya dilakukan dengan cara mendasarkan pada sanad Hadis. Pada bagian bukunya The Origins of Muhammadan Jurisprudence, terutama di bagian 'the evidence of isnad', Joseph Schacht mengajukan lima peraturan jika seseorang akan melakukan penanggalan Hadis beradasarkan sanad Hadis. Pertama, sanad yang paling sempurna dan lengkap adalah sanad yang paling belakangan; kedua, jika ditemukan ada banyak jalur sanad dalam suatu Hadis yang berakhir pada level periwayatan awal, misalnya generasi Tabiin, kemudian ada tambahan sanad yang berujung kepada otoritas tertinggi, maka sanad awal itu harus dianggap sebagai bersifat bukan yang utama, ini disebut kemudian sebagai teori backward projection; ketiga, variasi sanad yang muncul di sumber awal dengan penambahan otoritas atau periwayat merupakan produk pemalsuan; keempat, keberadaan common link dalam semua at au hampir pada semua Hadis merupakan indikasi kuat bahwa Hadis memang berasal dari waktu sosok common link; kelima, variasi sanad yang melewati common link adalah produk awal. ${ }^{70}$

Bagi Schacht, common link adalah pihak yang bertanggung jawab dalam sebuah Hadis, semacam persimpangan jalan antara sanad yang benar dan palsu. Sanad yang palsu adalah yang menyendiri, biasanya mengarah kepada level ke atasnya, dalam hal ini Tabiin dan Sahabat. Sanad yang sebenarnya terdiri dari beberapa jalur, dari common link ke para penulis kitab Hadis. Menurut Schacht, common link (CL) merupakan pihak pertama yang menyebarkan suatu Hadis, dalam artikulasi lain Hadis itu berasal dari generasi CL, CL ini biasanya merupakan generasi tabiin, paruh kedua abad kedua hijriyah $^{71}$

Selain Joseph Schacht, peneliti lain yang berusaha melakukan penanggalan Hadis didasarkan pada sanad Hadis adalah G.H.A Juynboll.

${ }^{68}$ Harald Motzki, "Dating Muslim Tradition, 216. Lihat Ozjān Khaḍr, "Manāhij alMustashriqīn fī Tārikh al-Ahādith,” Majallah al-Muslim al-Mu'āsir 32, 127.

${ }^{69}$ G.H.A. Juynboll, Muslim Tradition: Studies in Chronology, Provenance and Authorship of Early Hadith (Cambridge: Cambridge University Press, 1983), 130; Lihat juga Bekir Kuzudlesi, "Hadith of Man Kadhaba 'alayya 51.

${ }^{70}$ Harald Motzki, "Dating Muslim Tradition, 220.

${ }^{71}$ Harald Motzki, "Dating Muslim Tradition, 222. 
Keduanya sebenarnya menaruh hutang besar pada Joseph van Ess (lahir 1934). Ia setuju dengan Schacht terkait penafsiran terhadap CL dan bagian sanad yang berasal dari CL kepada generasi awal. Baginya CL merupakan pemilik Hadis, ia pihak pertama yang bertanggung jawab terhadap matan Hadis. Jalur tunggal dari CL menuju kepada Nabi merupakan bikinan CL. CL muncul berada pada level generasi Tabiin. ${ }^{72}$

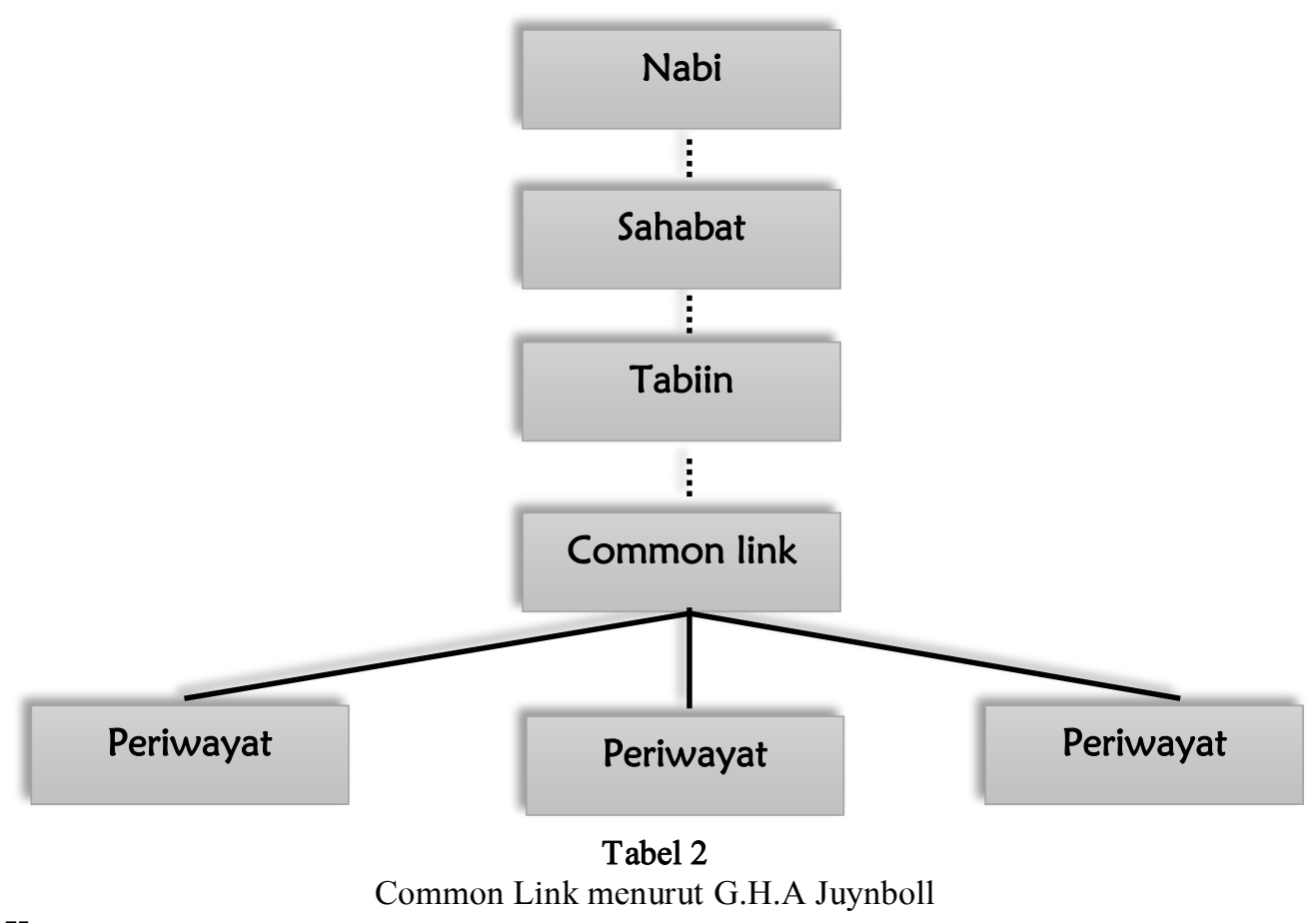

Keterangan:

Garis put us-put us merupakan sanad yang dipalsukan. Common link bertanggung jawab dalam memalsukan Hadis dan memalsukan sanad kepada Nabi.

Sarjana-sarjana yang disebut di atas, secara keseluruhan berkesimpulan bahwa Hadis Nabi berasal dari generasi belakangan. Sunnah sebagai refleksi Nabi terhadap al-Qur'an dan realitas sampai kepada kita melalui Hadis. ${ }^{73}$ Sunnah adalah bahan laporan, laporannya itu sendiri melalui Hadis. Sayangnya, sarjana tadi berpendapat bahan Hadis Nabi adalah Sunnah yang agak belakangan, menurut Juynboll CL berasal dari generasi Tabiin. Kajian terhadap asal-usul Hadis Nabi mengendap dalam kesimpulan yaitu bahwa secara waktu, Hadis berasal dari generasi belakangan, tidak berasal dari Nabi.

${ }^{72}$ G.H.A. Juynboll, Muslim Tradition, 369.

${ }^{73}$ Kuliah Umum Prof. Dr. Kamaruddin Amin pada acara Seminar Internasional Hadis di Yogyakarta 2016, dilaksanakan oleh Asosiasi Ilmu Hadis Indonesia (Asilha). 
Menurut 'Ajāj al-Khatīb adalah tidak benar jika khalifah Dinasti Umayyah mendorong untuk melakukan pemalsuan terhadap Hadis Nabi atau meminta kepada seseorang agar dibuatkan Hadis baginya untuk memuluskan siasat politiknya, menguatkan tujuannya. Di dalam al-La'āli al-Mașū'ah fí al-Ahàdith al-Mawdī'ah, terdapat riwayat berikut: Diriwayatkan dari Abū Anas al-Ḥarāni, al-Mukhtār al-Thaqāfî (salah seorang pembangkang Dinasti Umayyah), berkata kepada salah seorang aṣ̆āb al-hadith: "Buatkan untuk-ku satu Hadis dari Nabi SAW., bahwa setelah ia (wafat) akan ada khalifah yang akan menuntut anak cucunya ("itrat waladih). Ini sepuluh ribu dirham, perhiasan, kendaraan (dari hewan) dan pembantu". Lelaki dari ahli Hadis itu berkata: "Adapun dari Nabi saya tidak akan melakukannya, tetapi pilihlah siapa yang kau kehendaki dari Sahabat, turunkan harganya sekehendakmu, ia berkata dari Nabi lebih kuat, sedangkan siksa baginya teramat berat!. Menurut 'Ajāj al-Khatīb riwayat ini tidak benar sama sekali, sebagaimana riwayat ini berada dalam karya al-Suyūtị yang merupakan koleksi Hadis palsu. ${ }^{74}$

Goldziher menuduh 'Abdul Malik b. Marwān sebagai pemalsu Hadis. Menurutnya, 'Abdul Malik melarang orang-orang melaksanakan haji pada saat fitnah Ibn al-Zubayr, ia membangun qubbah di masjid al-Aqșā, agar orang-orang melaksanakan haji di sini, melakkan thawaf di sekelilingnya sebagai pengganti Ka'bah, lalu mendorong oang-orang berhaji ke sana dengan argumentasi teologis. Ia menuduh al-Zuhri sebagai orang yang bertanggung jawab menyebarkan Hadis lā tushadd al-riḥăl illa ilā thalāts masājid. Setidaknya ada empat konsiderasi Goldziher terkait peran al-Zuhri sebagai pemalsu Hadis: pertama, "Abdul Malik melarang orang-orang Shām melaksanakan ibadah haji ke Mekkah; kedua, 'Abdul Malik membangun Qubbah Besar di Masjid al-Aqșā' agar orang-orang melaksanakan haji di Palestina; keitga, mendorong orang-orang berhaji ke Palestina menggunakan Hadis yang dibuat oleh al-Zuhri, seorang ahli Hadis terkenal; keempat, argumentasi bahwa al-Zuhri sebagai pemalsu Hadis ini adalah bahwa ia sahabat dekat 'Abdul b. Marwan, sering bolak-balik ke istana, bahkan HadisHadis yang berisi tentang keutamaan bayt al-Maqdis diriwayatkan melalui jalur al-Zuhrī. ${ }^{75}$

Menurut 'Ajāj al-Khatīb adalah mustahil Abdul Malik b. Marwan melarang orang-orang Shām melarang melaksanakan haji ke Mekkah, haji adalah kewajiban setiap muslim yang mampu, bagaimana bisa ia menunda atau melarang orang melaksanakan syi'ar Allah, padahal ia dikenal sebagai ahli ibadah dan tukang berbuat kebaikan, bahkan al-Zuhri dianggap sebagai

74 Muhammad 'Ajāj al-Khatīib, Aḍ̂à' 'alā al-'I'lām fì Sadr al-Islām (Beirut: Mu'assasah al-Risālah, 1985), 126.

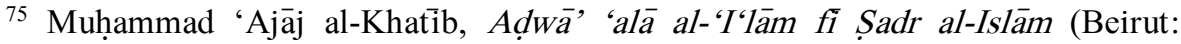
Mu’assasah al-Risālah, 1985), 127. 
ahli fikih Madinah. Menurut Abū al-Zinād, ahli fikih Madinah ada empat: Sa īid b. al-Musayyab, 'Urwah b. al-Zubayr, Qabișah b. Dhuayb dan 'Abdul Malik b. Marwān. Sumber-sumber Islam tidak menyebutkan Abdul Malik b. Marwan sebagai pembuat Qubbah besar, yang membuat adalah anaknya alWalid. Menurut Muștafā al-Sibā $\mathfrak{i}$, kita tidak menemukan bahwa sumbersumber Islam menyebutkan, meski satu riwayat saja, bahwa yang membangun Qubbah itu adalah Abdul Malik b. Marwān. Tidak diragukan lagi bahwa Qubbah itu adalah perkara baru bahkan paling baru dalam sejarah Islam dan paling penting di dalam sejarah Islam. ${ }^{76}$

Adalah Harald Motzki yang melakukan penanggalan terhadap Hadis Nabi dengan kesimpulan yang berbeda dari sarjana di atas. Ia menyebut metode yang digunakannya sebagai metode isnad cum matn analysis. Jika sarjana di atas dalam melakukan penanggalan terhadap Hadis Nabi didasarkan semata-mata pada matan Hadis, atau sanad Hadis sendiri, tidak demikian dengan Motzki, ia memadukan kajian terhadap matan dan sanad Hadis sekaligus secara bersamaan.

Memahami bahwa penanggalan terhadap asal-usul Hadis jika didasarkan pada kajian matan saja atau sanad saja tidak memadai, Motzki memandang perlu jika asal-usul Hadis Nabi dilihat baik melalui sanad dan matan sekaligus. Ada lima langkah yang bisa dilakukan untuk mengoperasikan metode ini. Pertama, seluruh variasi Hadis yang memiliki tema serupa dikumpulkan. Kedua, variasi rangkaian sanad disusun dalam suatu diagram untuk melihat proses periwayatan seperti direfleksikan oleh jalur periwayatan dan untuk mendeteksi partial common link dan common link itu sendiri. Sesuai penafsiran yang diajukan, ketika mendiskusikan common link, unt uk sement ara CL dianggap sebagai pengumpul dan penyebar profesional Hadis, ketiga, apakah CL bisa dianggap sebagai pengumpul Hadis sebenarnya atau penyebar profesional Hadis harus dibuktikan dengan melakukan analisa terhadap matan Hadis. Ia berguna dalam menyusun sebuah teks Hadis sesuai dengan jalur periwayat annya untuk membuat perbandingan sinoptik satu matan dengan matan lainnya, keempat, pengelompokan variasi matan dan variasi sanad dilakukan untuk mengetahui apakah ada hubungan atau tidak, kelima, jika terdapat korelasi, maka kesimpulan bisa diturunkan terkait matan asli yang diriwayatkan oleh CL dan seseorang yang bertanggung jawab apakah perubahan terjadi dalam periwayatan setelah CL. ${ }^{77}$

Metode ini digunakan Motzki untuk menanggal Hadis dan hasilnya mencengangkan. Ia berkesimpulan bahwa asal-usul Hadis bisa lebih tua ketimbang hasil penanggalan versi Goldziher, Schacht dan Juyunboll. Dalam

${ }^{76}$ Muhammad 'Ajāj al-Khatīib, Aḍ̂ā' 'alà al-'I'lām fị Sadr al-Islām (Beirut: Mu’assasah al-Risālah, 1985), 128.

${ }^{77}$ Harald Motzki, "Dating Muslim Tradition”, 251. 
artikel berjudul The Musannaf of 'Abd al-Razzāq al-Ṣan 'ānì As a Source of Authentic Ahàdith of the First Century", ia membuktikan bahwa Hadis bisa ditanggal kemunculannya pada abad pertama hijiryah. ${ }^{78}$

Sekali lagi, kajian-kajian terdahulu terkait asal-usul (origins) atau penanggalan (dating) Hadis terfokus kepada ukuran waktu, yaitu kapan sebuah Hadis muncul. Ini tidak saja pincang, selain kesimpulan sarjana Barat yang memandang kemunculan Hadis lebih belakangan seperti disebutkan di awal, dan juga sanggahan beberapa sarjana muslim terhadap tesis sarjana Barat, mengingat Sunnah Nabi atau Hadis Nabi lahir tidak saja dalam konteks waktu. Satu hal yang kemudian penting diperhatikan adalah di mana sebuah Hadis lahir, muncul dan kemudian menyebar. Regionalism merupakan salah satu kajian yang kiranya penting diterapkan terhadap studi Hadis, sebagai sebuah fakta historis gerakan intelektual tiga abad pertama hijriyah.

Seperti akan dijelaskan pada sub bab berikut ini, alasan mengapa faktor tempat penting dalam studi Hadis adalah bahwa memang secara spesifik tempat penyemaian sunnah Nabi adalah Mekkah-Madinah, tetapi belum sebagai sebuah korpus yang terbuka, Nabinya masih hidup, mengaktual, siapapun jika ingin mengetahui segala sesuatu tinggal ditanyakan langsung kepada Nabi, jawabannya pun seketika didapatkan. Kepentingan studi kawasan, atau tepatnya mengetahui kemunculan dan penyebaran Hadis Nabi adalah diinisiasi oleh kenyataan bahwa proses verbalisasi sunnah nabawiyah (Hadis) muncul justeru setelah Nabi wafat dan orang yang melakukannya tidak hanya terkonsentrasi di Mekkah-Madinah. Seperti dikatakan oleh Fazlur Rahman, bahwa proses terjadinya Hadis bermula dari teladan Nabi SAW., dipraktikkan oleh para sahabat, ditafsirkan oleh individu, opinion generasi, opinion publica baru formalisasi sunnah itu menjadi Hadis.

\section{Tempat Sebagai Parameter Asal-Usul Hadis}

Sebelum sunnah atau Hadis Nabi menjadi arus utama objek kesadaran masyarakat muslim awal, sumber ajaran Islam bertumpu kepada al-Qur'an, karena itu al-Qur'an diperlakukan sedemikian rupa penting dan masif. Usahausaha menjaga kesucian dan kemurniannya tidak diragukan lagi. Dihapal dalam memori kolektif para Sahabat, ditulis di tulang hewan, pelepah kurma, kulit hewan dan lainnya, hingga al-Qur' an dibukukan sebagai sebuah korpus resmi pada masa khalifah 'Uthmān b. 'Affān (w. 35), kelak usahanya ini

78 Harald Motzki, "The Muṣannaf of Abdul Razzāq al-Ṣan'ānī as A Source of Authentic Ahādith in the First Century," Journal of the Near Eastern Studies 50 (1990): 121. Stephen J Shoemaker, "In Seacrh of Urwa's Sira: Some Methodological Issues in the Quest for the Authenticity in the Life of Muhammad," Der Islam 85 (2011): 267. 
dikenal sebagai muṣhaf 'uthmānī. ${ }^{79}$ Pada masa itu al-Qur' an dicetak empat eksemplar, kemudian dibagikan ke kota-kota besar yang berkembang pada saat itu; Mekkah, Madinah, Küfah, Bașrah dan Suriah. ${ }^{80}$

Apa yang bisa dipahami dari kebijakan khalifah ini adalah, sekali lagi dipandang perlu adanya pegangan keagamaan di daerah-daerah yang baru tumbuh seiring laju ekspansi Islam. Bagaimana pun, ekspresi Islam menghendaki adanya titik keseragaman dan ketersambungan ajaran sejak masa Nabi hingga masa-masa belakangan. Sebut saja kota-kota itu sebagai lokal, kecuali Madinah dan Mekkah umpamanya, yang harus memiliki keterhubungan dengan sumber otentik Islam, yaitu Hijāz saat itu. Lokalitas daerah-daerah bertumbuh dibangun oleh pribadi-pribadi (personal) tangguh menuju universalitas Islam. Sebaran geografis al-Qur'an di sebuah daerah, pada saat yang sama mensyaratkan adanya pribadi-pribadi sebagai agen penyebar, dalam hal ini para Sahabat Nabi, ketersambungan dan keberlangsungan sebuah doktrin keagamaan berlangsung.

Joseph Schacht pada 1950 menulis The Origins of Muhammadan Jurisprudence menjadi awal bagi munculnya kajian terhadap sejarah hukum Islam, demikian juga Hadis Nabi dalam kerangka geografis-antropologis. Fokus kepada tulisan Muhammad b. Idrīs al-Shāfi'i (w. 204/820), Schacht menjelaskan transisi yang berujung kepada kemunculan madzhab formal hukum Islam (fikih), meski sudut pandang Schacht terkait transformasi hukum Islam dari lokal (regionalism) ke personal kemudian menjadi universal hukum Islam, misalnya kemudian hari ditantang oleh Wael B. Hallaq. Wael mempertanyakan keberadaan mazhab hukum lokal dan berargumentasi bahwa level awal perkembangan hukum Islam berawal dari mazhab perseorangan seorang ahli hukum Islam. Meski begitu, hal ini tidak menafikan pentingnya klaim regionalism tentang tulisan hukum Islam misalnya, atau sirah dan Hadis Nabi. Bahkan umpama pun tidak ada mazhab regional, besar kemungkinan tempat tinggal seorang ahli hukum Islam di sebuah kota tertentu akan dipengaruhi oleh praktik ritual lingkungannya. ${ }^{81}$ Athār sebagai sumber utama untuk mengkaji peristiwa 150 tahun pertama Islam, pun berisi berbagai macam literatur Hadis, baik awal maupun agak belakangan dari berbagai kota, suku dan sekte. Menentukan tanggal dan tempat kemunculan sebuah Hadis atau laporan merupakan tugas kompleks yang membutuhkan pengembangan metode. Misalnya, bisa dilakukan dengan menghubungkan antara isi suatu

${ }^{79}$ Gregor Schoeler, "The Constitution of Koran as a Codified Work: Paradigm for Codifying Hadith and the Islamic Sciences," Oral Tradition 25/1 (2010): 201, 204.

80 Behnam Sadeghi, "The Traveling Tradition Test: A Method for Dating Tradition," Der Islam, Bd. 85 (2010): 206.

81 Najam Iftikhar Haider, "The Geography of Isnād: Possibilities for the Reconstruction of Local Ritual Practice in the $2^{\text {nd }} / 8^{\text {th }}$ Century," Der Islam 90, 2 (2013): 307. 
Hadis (matan) dengan kota atau tempat sebagaimana ditunjukkan oleh rangkaian isnäd untuk menentukan bundle tanggal Hadis. ${ }^{82}$

Nampaknya memang adalah Joseph Schacht yang memiliki minat serius meneliti asal-usul Hadis berdasarkan kajiannya dalam The Origins of Muhammadan Jurisprudence. Kajian kesarjanaan kekinian mengamini kesimpulan bahwa pada akhir abad pertama hijriyah dan awal abad kedua hijriyah merupakan fase terbentuknya jaringan individual ahli hukum Islam yang merepresentasikan living tradition atau tradisi yang hidup atau praktik kebiasaan sebuah kota atau lokalitas. ${ }^{83}$ Pada paruh ke-2 abad ke-2 hijriyah terdapat perkembangan mazhab hukum personal yang terorganisir sebagai sebuah otoritas seperti Abū Ḥanifah (w. 150/767) di Küfah dan Mālik b. Anas di Madinah (w. 179/795). Dua ahli hukum Islam ini merupakan saluran praktik lokal meskipun didasarkan pada ra'y dalam formulasi hukumnya. Bersamaan berkembangnya hukum Islam yang personal, masyarakat muslim juga mengalami perkembangan tradisionalisme, yaitu gerakan keagamaan yang menekankan kepada repetisi terhadap otoritas normatif sebuah teks (Hadis yang menjaga pendapat Nabi, Sahabat dan Tabiin) di dalam formulasi hukum. Al-Shāfi ${ }^{\circ} \mathfrak{i}$ (w. 204) merupakan representasi titik keseimbangan antara dua cara pandang hukum, meski pada akhirnya dia berpengaruh besar dalam superioritas kalangan tradisionalisme (aṣhāb al-hadith) ketimbang aṣhāb alra'y. Dengan demikian, regionalism merupakan elemen penting dalam diskursus hukum seperti disebutkan di atas. Mazhab hukum Islam yang berkembang dan menyebar di kawasan atau daerah muslim pada masa awal kemungkinan dipengaruhi oleh adat-istiadat daerah urban sejak awal abad ke2 hijiryah. ${ }^{84}$

Patricia Crone (w. 2015) dalam Roman, Provincial and Islamic Law, menyebut hukum Romawi mempengaruhi hukum Islam. Sampai pada kesimpulan itu, ia fokus membahas ke dalam institusi patronase (al-wallā') dan berusaha untuk membuktikan bahwa formula patronase berasal dari kedaerahan (provincial) hukum Romawi, ketimbang berasal dari tradisi masyarakat Arab pra-Islam. ${ }^{85}$ Crone berpendapat praktek hukum yang bersifat

${ }^{82}$ Behnam Sadeghi, "The Traveling Tradition Test, 203.

${ }^{83}$ Menurut Najam Iftikhar Haider, ini diderivasi dari Joseph Scahcht dalam The Origins of Muhammad Jurisprudence 6-10, 58-81, 228-257. Wael B. Hallaq, Origins and Evolution of Islamic Law (Cambridge: Cambridge University Press, 2004), 63-68, 74-78, and 153-167; dan Christopher Melchert, Formation of the Sunni School of Law $9^{\text {th }}-10^{\text {th }}$ CE (Leiden: Brill, 1997), 32-47.

${ }^{84}$ Najam Iftikhar Haider, "The Geography of Isnād, 307-308.

85 Patricia Crone, Roman, Provincial and Islamic Law (Cambridge: Cambridge University Press, 1987), 88; Akh. Minhaji, Islamic Law and Local Tradition: A SocioHistorical Approach (Yogyakarta: Kurnia Alam Semesta, 2008), 77. 
provincial (kedaerahan) di Syria, ibu kota dari sebuah negara Islam yang baru lahir sangat berpengaruh besar terhadap institusi syari' ah di kemudian hari. ${ }^{86}$

Kronologi hukum Islam menurut Crone memiliki beberapa tingkat. Hukum klasik dikembangkan oleh para ulama beberapa abad setelah mengamandemen dan mengganti peraturan terdahulu dan menghubungkannya kepada Hadis Nabi. Ini terutama sekali didasarkan pada hukum provincial yang ada di Timur Jauh, bagian dari Syria. Praktik hukum kedaerahan ini meskipun memproklamirkan diri berasal dari Romawi, faktanya berasal dari penggabungan dari banyak praktik hukum sebelum Islam dan sebelum hukum Romawi, yaitu hukum Yunani.

Untuk membuktikan klaimnya itu, Crone mengambil contoh isu hukum yang kontroversial secara politik, yaitu bagaimana integrasi masyarakat Islam non-Arab dengan masyarakat Arab muslim. Sebagai agama universal, Islam tidak mengecilkan hati orang-orang baru dari daerah taklukan untuk bergabung dalam agama Islam ataupun komunitas muslim. Tapi, penakluk mengangkat masyarakat kesukuan dan membutuhkan metode asimilasi anggota baru ke dalam komunitas muslim awal. Maka diperkenalkanlah istilah client (mawlā) yang bertahan beberapa abad. Sistem ini memaksa muslim baru menjadi kelas kedua, sistem ini kemudian dihapuskan oleh revolusi Dinasti Abbasiyah. Pertanyaannya adalah dari mana sistem ini berasal? Crone beragumentasi, konteksnya memang berasal dari sebelum masyarakat Arab Islam, bentuknya diambil atau dipinjam dari hukum Romawi, pada pertama kali melalui proses yaitu penyebarannya di provinsi Timur Dekat, berikutnya meminjamnya secara langsung dari hukum Romawi secara tepat. ${ }^{87}$

Najam Iftikhar Haider mencoba memperkenalkan apa yang ia sebut sebagai the geography of isnād untuk merekonstruksi praktik ritual abad ke2 hijriyah di beberapa kota besar: Mekkah, Madinah, Küfah dan Irak. Ia ingin melihat hubungan antara mazhab hukum Islam dan kawasan atau kota, untuk merekonstruksi praktik dominan mayoritas muslim pada abad ke-2 hijiryah. ${ }^{88}$

Mula-mula ia melakukan pemetaan asosiasi geografis mazhab hukum Islam dengan kota dimaksud. Mazhab dimaksud terdiri 4 mazhab Sunni

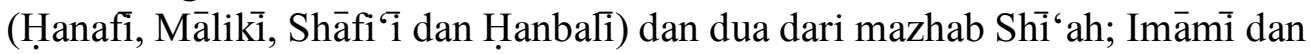
Zaydi.

${ }^{86}$ Kritik terhadap pandangan ini, lihat Wael B. Hallaq, "The Use and Abuse of Evidence: the Question of Provincial and Roman Influences on Early Islamic Law," Journal of the American Oriental Society, Vol. 110, no. 1 (Jan-March, 1990): 79.

${ }^{87}$ Knut S. Vikor, "The Origins of the Sharia", 19. Dalam Rudolp Peters \& Peri Bearman (ed), The Asghate Research Companion to Islamic Law (London: Routledge, 2014).

${ }^{88}$ Lihat artikel Najam Iftikhar Haider, "The Geography of the Isnad: Possibilities for the Reconstruction of Local Ritual Practice in the $2^{\text {nd }} / 8^{\text {th }}$ Century", Der Islam, 90 (2) (213): 306-346. 


\begin{tabular}{|c|c|c|}
\hline Mazhab & Asosiasi-geografis & Kekuatan \\
\hline Hanafí & Kūfah & Kuat \\
\hline Mālikì & Madinah & Kuat \\
\hline Shāfi ${ }^{`}$ & Madinah & Moderat \\
\hline Ḥanbali & Irak & Lemah \\
\hline Imāmī/Zaydis & Kufa (komunitas) Madinah (Imām & Keduanya kuat \\
\hline
\end{tabular}

Tabel 3

Asosiasi Mazhab Hukum Islam dengan Wilayah

Haider menguji asosiasi-geografis dengan mazhab itu melalui dua variable, pertama, pembacaan basmalah al-Fātiḥah ketika shalat, kedua, pembacaan qunut.

\begin{tabular}{|c|c|c|c|}
\hline Mazhab & $\begin{array}{l}\text { Basmalah sebagai ayat } \\
\text { pertama surat al-Fātihah } \\
\text { dan surat lainnya? }\end{array}$ & $\begin{array}{l}\text { Basmalah dibaca } \\
\text { pada permulaan } \\
\text { shalat }\end{array}$ & $\begin{array}{l}\text { Pembacaan } \\
\text { basmalah }\end{array}$ \\
\hline Ḥanafí & Bukan & Iya & Pelan \\
\hline Mālikì & Bukan & Bukan & Tidak digunakan \\
\hline Shāfi`i & Iya & Iya & $\begin{array}{l}\text { Bersuara } \\
\text { Pelan }\end{array}$ \\
\hline Hanbali & Bukan (ayat independenI & Iya & Pelan \\
\hline Imāmì & Iya & Iya & Bersuara \\
\hline Zaydi & Iya & Iya & $\begin{array}{l}\text { Mayoritas: } \\
\text { bersuara sesuai } \\
\text { shalat dan pelan } \\
\text { sesuai jenis } \\
\text { shalat. Pandangan } \\
\text { minoritas: } \\
\text { bersuara. }\end{array}$ \\
\hline
\end{tabular}

Tabel 4

Cara Membaca Basmalah Menurut Mazhab Hukum Islam

Berdasarkan tabel di atas, dapat diambil konsiderasi sebagai berikut: Mekkah: basmalah dibaca dan bersuara (dibaca pelan sebagai potensi minor). Madinah: basmalah dibaca dan bersuara (kelalaian sebagai potensi minor). Küfah: seimbang antara dibaca (keras) dengan pelan. Basra: tidak dibaca (dibaca keras sebagai potensi minimal).

Berdasarkan studi kasus terhadap bacaan basmalah dalam salat, secara umum mendukung asumsi kesarjanaan tentang asal-usul geografis hukum Islam kontemporer. Seperti diharapkan, Ḥanafi secara umum berada di Küfah, 
Ḥanbali secara lebih luas berada di konteks Irak, Shāfi ‘i di Madinah, demikian juga Imāmì dan Zaydi di Küfah (komunitas) dan Madinah. ${ }^{89}$

Sarjana lainnya Behnam Sadeghi memiliki perhatian seperti Najam Haider. Ia menganggap penting kajian geografis terhadap Hadis Nabi. Ke arah itu, ia memperkenalkan metode penanggalan terhadap asal-usul Hadis Nabi melalui The Traveling Tradition test: A Method for Dating Tradition. ${ }^{90}$ Menurutnya, sejak awal sumber-sumber Islam awal berwatak regionalism, maksudnya mewakili apa yang disebutnya sebagai geographic clustering isi sumber itu. Tiap kota memiliki bahasa yang berbeda, demikian juga stilistika dan profil hukumnya. Suatu Hadis tentang tema tertentu dari sebuah kota tertentu seringkali menggunakan narasi, kosa kata, frase, struktur sintaksis dan produk hukum yang unik atau secara khusus, khas kota tersebut. Sebagai contoh, frase là a lamu secara tak sebanding digunakan oleh orang Bașrah untuk mengekspresikan ketidaksetujuan bagi suatu tindakan atau bagian produk legislasi. Contoh lainnya, hanya ahli Küfah yang menggunakan kata rukhșa merujuk kepada izin bagi seorang perempuan dalam konteks Salat '⿳一, atau kata lain seperti manqal. Faktanya, adakalanya seseorang bisa menggunakan artikulasi tertentu untuk menebak secara tepat tempat lahir sebuah Hadis, bahkan sebelum melihat ke isnād Hadis dimaksud. ${ }^{91}$

Kadar regionalisme dalam bidang hukum bisa bisa ditujukan dalam suatu contoh. Silahkan pilih hukum yang kontroversial secara acak dari ribuan masalah hukum dalam karya Ibn Abi Shaybah Musannaf. Kumpulkan semua Hadis dan semua varian topiknya dari semua sumber tercetak yang tersedia. Lalu gunakan jalur periwayatannya (isnād) untuk mengidentifikasi tempatnya masing-masing, biasanya tiap peneliti akan menemukan kadar regionalism. ${ }^{92}$

Sebenarnya studi kawasan terhadap Hadis Nabi bukan sesuatu yang baru, ulama Hadis klasik sudah memperkenalkan studi itu, mereka menggunakan term madrasah al-hadith. Studi itu, misalnya studi kawasan Hadis Mekkah, Madinah, Kūfah, Bașrah, Shām, Qayrwān, Yamān. Rasionalisasi bahwa studi kawasan patut dijadikan perspektif dalam studi Hadis adalah bahwa Hadis melewati orang-orang dari berbagai lint as generasi, sejak masa Sahabat, Tabiin dan generasi berikutnya, mutaqiddimin dan muta'akhirin. Bermula dari satu titik, sunnah Nabi lalu Hadis menyebar ke berbagai wilayah di belahan muka bumi ini, secara waktu sejak masa Nabi hingga kini, secara tempat dari Mekkah-Madinah, ke daerah barat hingga ke

${ }^{89}$ Najam Haider, "Mu'âwia in the Hijāz: The Study of a Tradition": 43-55, dalam M. Cook et all, Law and Tradition in Classical Islamic Thought: Studies in Honor of Professor Hossein Modarressi (New York: Palgrave MacMillan, 2013).

${ }^{90}$ Behnam Sadeghi, "The Traveling Tradition Test: A Method for Dating Tradition" Der Islam 85 (2010).

${ }^{91}$ Behnam Sadeghi, “The Traveling Tradition Test, 204.

${ }^{92}$ Behnam Sadeghi, "The Traveling Tradition Test, 206. 
Andalusia, timur ke kawasan Asia Selatan, seperti disinggung oleh alDhahabi. ${ }^{93}$

\section{Regionalisme Dalam Mendeteksi Sebaran Hadis Sahabat}

Sampainya sunnah nabawiyah ke Küfah secara khusus dan Irak secara umum tidak se-mushkil dan serumit membayangkan Nabi melakukan perjalanan ke Irak untuk melakukan dakwah secara langsung ketika beliau masih hidup pada abad ke-7 masehi. Tidak pernah disebutkan dalam literatur sejarah Islam awal bahwa Nabi pernah melakukan perjalanan jauh ke Küfah. Yang didokumentasikan al-Qur'an, Nabi pernah melakukan perjalanan bisnis ke Shām. ${ }^{94}$ Meski begitu, kemudian kita akan menemukan fakta bahwa Küfah pada akhir abad pertama, awal abad kedua hijriyah sudah ditinggali oleh sejumlah Sahabat Nabi. Ketidakmungkinan tidak sampainya dakwah Nabi ke daerah luar Hijāz tidak terbukti dengan demikian. Kelak Küfah dan Irak secara umum mampu mengimbangi Hijāz, terutama Madinah di dalam diskursus Hadis Nabi. Mengapa demikian? Kontinuitas doktrin keagamaan tidak berhenti seiring wafatnya Nabi, para Sahabat berfungsi sebagai 'gardu-gardu' penyambung risalah yang dibawa Nabi untuk disampaikan kepada manusia.

Ahli Hadis abad ke-8 al-Dhahabi (w. 748) menulis risalah kecil berjudul al-Amșār Dhawāt al-Äthār. Semacam buku ensiklopedia, di dalamnya penulisnya mendaftar kawasa-kawasan Islam masa lampau yang menurut penulisnya memiliki jejak peninggalan sunnah Nabi beserta tokohtokoh berpengaruh di masing-masing wilayah itu. Ringkasnya, ia mendaftar nama kota yang menjadi pusat studi Hadis sejak generasi pertama Islam yaitu Sahabat hingga generasi belakangan. Dari catatan itu, tergambar jelas bahwa Hadis Nabi menyebar tidak saja di Ḥijāz tapi menjangkau daerah terluar, misalnya Spanyol. ${ }^{95}$ Apa yang hendak disampaikan penulis di sini adalah bahwa kesadaran meruang merupakan kesadaran intelektual ulama masa lalu. Menempatkan seseorang dengan atau di dalam ruangnya untuk kemudian memeriksa hasil pemikirannya adalah pengalaman intelektual yang luar biasa.

Jauh sebelum al-Dhahabi menulis kitab itu, pada akhir abad ke-2 hijriyah Ibn Sa'd (w. 230) menulis kitab tebal Kitāb al-Tabaqāt al-Kabìr. Sebagai kamus biografis di dalamnya Ibn Sa'd menyajikan sejarah Nabi Muhammad dan dua generasi setelahnya yaitu Sahabat dan Tabiin. Dua jilid pertama menjelaskan biografi Nabi Muhammad, jilid ketiga dan keempat membahas biografi Sahabat Nabi, jilid kelima menyajikan biogragis periwayat Hadis dari Madinah, jilid keenam periwayat Hadis Küfah, ketujuh

${ }^{93}$ Lihat buku al-Dhahabī, al-Amșār Dhawāt al-Āthār (Beirut: Dār ibn Kathīr, 1985). Buku 134 halaman ini menyajikan data pusat-pusat studi Hadis sejak masa Sahabat hingga abad belakangan dan tokoh-tokoh hadis di setiap tabaqah-nya.

${ }^{94}$ Q.S Quraish [106]: 2.

${ }^{95}$ Al-Dhahabì, al-Amșār Dhawāt al-Āthār (Beirut: Dār ibn Kathīr, 1985) 
dari Bașrah dan Baghdad, dan kedelapan Sahabat perempuat dan periwayat Hadis dari kalangan perempuan. ${ }^{96}$ Demikian juga Khalifah b. Khayyāt (w. 240) menyusun kamus biografis Tabaqāt Khalifah $b$. Khayyāt, di dalamnya penulisnya menyajikan orang-orang yang berjasa pada masa awal Islam. 'Ali b. al-Madini (w. 234) menulis buku tentang sejumlah Sahabat Nabi yang berpencar ke berbagai kota pada masa awal Islam dalam Ma'rifat Man Nazala min al-Sahāābah Săir al-Buldān, dalam lima jilid buku. ${ }^{97}$ Mūsā b. Sahl b. Qādim al-Ramli (w. 261) menulis kitab Tasmiyat man Nazala Filisținn min alSahăbah, ${ }^{98}$ Abū Zur'ah al-Dimashqi (w. 281) menulis Tasmiyat man Nazala al-Shām min al-Anșār wa Qabā'il al-Yamān min al-Sahābah, ${ }^{99}$ Muhammad b.

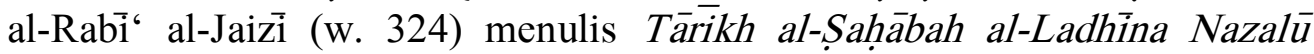
Miṣr ${ }^{100}$ Abū al-Qāsim 'Abd al-Ṣamad Abū Sa î̀d al-Ḥimṣi (w. 324) menulis Ma'rifat Man Nazala Hims min al-Saḥābah, ${ }^{101}$ Muhammad b. Sa id b. 'Abduraḥmān al-Qushayrì al-Ḥarrāni (w. 334) menulis Tärikh al-Raqqah wa man Nazalahā min Aṣ̣āo Rasulillāh wa al-Tābi īn wa al-Fuqahā wa alMuhaddithīn,, 102 'Abd al-Jabbār b. 'Abdullāh al-Khūlānì (w. 370) menulis Tārikh Dārayā wa man Nazala bihā min al-Saḥābat wa al-Tābi 'in wa Täbi' al-

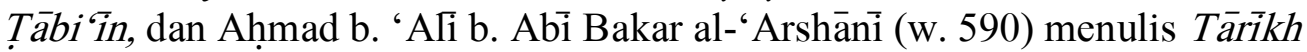
man Dakhala al-Yamān min al-Saḥābah.

Buku-buku tersebut secara tersirat hendak mengatakan dua hal kepada kita, pertama, fakta bahwa Sahabat Nabi baik pada masa Rasulullah terutama pasca Nabi meninggal dunia, tidak terkonsentrasi di sebuah kawasan tertentu, misalnya Mekkah dan Madinah, padahal terminologi Sahabat Nabi secara ontologis ada karena seseorang bertemu atau sejaman dengan Nabi dan fakta bahwa Nabi tinggal di Hijāz. Penulis buku-buku itu sadar bahwa, Sahabat Nabi pasca Nabi wafat menjadi tokoh yang memiliki tanggung jawab untuk menyebarkan ajaran Nabi ke berbagai kawasan, tentu saja di luar Hijāaz. Kedua, bahwa kota-kota yang seperti disebut dalam judul buku tadi, memiliki keistimewaan sendiri karena dengan sendirinya, kota dimaksud menjadi

${ }^{96}$ Aḥmad Nazir Attasi, “A History of Ibn Sa‘d’s Biographical Dictionary Kitāb alṬabaqāt al-Kabīr,": 1.

${ }^{97}$ Nūruddin 'Ițr, Manhaj al-Naqd fì 'Ulūm al-Hadith (Damaskus: Dār al-Fikr, 1979) 116; Muhammad b. Ja'far al-Kattānī, al-Risālah al-Mustatrafah li-Bayān Mashhūr Kutub alSunnah al-Musharrafah (Beirut: Dār al-Bashāir al-Islāmiyyah, 1993), 127.

${ }^{98} \mathrm{Abū}$ Nu'aim al-Iṣfahānī, Ma 'rifat al-Saḥābah (t.tp: Dār al-Waṭan li al-Nashr, t.t) 3: 1399 .

${ }^{99}$ Disebutkan oleh Ibn ‘Asākir dalam Tārīkh Madinah Dimashq (Beirūt: Dār al-Fikr, t.t), 9: 65 .

${ }^{100}$ Al-Dhahabī, Mizān al-I'tidāl fỉ Naqd al-Rijāl(Beirut: Dār al-Ma'rifat, t.t), 1: 121.

101 Al-Mizzì, Tahdhīb al-Kamāl fì Asmā' al-Rijāl (Beirut: Muassasah al-Risālah, 1983), 34: 150 .

102 'Abd al-Latịif al-Samlāli, "Darr al-Ṣaḥābah fiman Dakhala Miṣr min al-Ṣaḥābah li-Jalāluddin al-Suyūṭi”, http://www.oqba.ma/Article.aspx?C=5663. Akses 8/2/2017. 
memiliki otoritas dalam aspek keagamaan. Oleh karena itu, seperti disebutkan oleh penulis manāqib Sahabat, Sahabat Nabi memiliki keutamaan terutama sekali karena mereka pernah sejaman bahkan hidup bersama Nabi, pada saat yang sama kawasan yang ditinggali Sahabat memiliki kemuliaan tersendiri dibandingkan kawasan lain yang tidak pernah ditinggali Sahabat Nabi. ${ }^{103} \mathrm{Hal}$ ini tidak bisa dilepaskan dari cara pandang masyarakat muslim awal yang didasarkan pada Hadis Nabi. Nabi dilaporkan pernah menyatakan bahwa generasi terbaik adalah generasi Nabi, lalu Sahabat dan era pasca Sahabat Nabi. ${ }^{104}$

Hadis sebagai peninggalan Nabi yang utama setelah al-Qur'an, sebelum dikodifikasi pada abad ke-3 hijriyah dilestarikan oleh Sahabat Nabi. Bahwa pasca Nabi wafat pusat otoritas dan politik ada di Madinah benar dalam konteks sampai akhir khalifah ke-3 'Uthmān b. 'Affān. Fitnah berupa Perang Sipil karena terbunuhnya Khalifah ke-3 dan konfigurasi politik setelahnya, secara masif menggerakkan Sahabat Nabi berpencar ke berbagai wilayah, dengan begitu perpindahan Sahabat ke berbagai wilayah baru, secara otomatis wilayah baru yang ditinggali oleh seorang Sahabat Nabi misalnya, dalam skala kecil akan membuat wilayah itu memiliki karisma dan pengaruh.

Dalam alur berfikir seperti itu, kita akan mengamini konsiderasi akademik yang dikemukan oleh Joseph Schacht bahwa mazhab hukum Sunni bersifat lokal dan regional. ${ }^{105}$ George Makdisi mencatat tiga langkah evolusi hukum Islam, pertama, regional school (ketika ahli hukum mengidentifikasi praksis hukum kepada yang berkembang di beberapa kota atau provinsi), kedua, personal school (ketika ahli hukum secara sadar mengidentifikasi praksis hukumnya kepada salah seorang ahli hukum), ketiga, guild school (masih pribadi tapi sekarang telah mengakui 'kepala suku' setempat dan mengklaim wewenang eksklusif untuk mengatur pengajaran dan praktik hukum). ${ }^{106}$

Perdebatan akademik di kemudian hari terjadi terkait hukum Islam antara ahl al-ra'y dan ahl al-hadith yang diidentifikasikan sebagai yang pertama Küfah dan kedua Madinah atau lebih spesifik lagi antara Hanafism dan Malikism bisa dijelaskan dan dipahami jika kita melakukan kajian

${ }^{103}$ Fu'ad Jabali, Sahabat Nabi: Siapa, Kemana dan Bagaimana (Bandung: Mizan, 2010).

${ }^{104}$ Bukhāri, [kitāa faḍ̄àil așhạab al-Nabī]; Muslim, [kitāb faḍā'il al-șahāāah].

105 Joseph Schacht "The School of Law and Later Development of Jurisprudence," Law in the Middle East: 57-85.

106 Christopher Melchert, "How Hanafism Came to Originate in Kufa and Traditionalism in Medina," Islamic Law and Society (1999): 319. 
biografis sekaligus geografis. Mazhab personal hukum Islam Hanafi dan Māliki, diderivasi dari mazhab regional Küfah dan Madinah awal. ${ }^{107}$

Oleh karena Hadis terdiri dari sanad dan matan dan fakta bahwa sanad Hadis setidaknya terdiri dari tiga bahkan lebih dari empat tabaqah maka kajian regionalism terhadap Hadis Nabi adalah usaha untuk menanggal atau menentukan sebuah Hadis yang sejumlah periwayatnya berasal dari satu daerah. Dalam konteks penelitian ini, variabel ut amanya adalah Sahabat Nabi yang tinggal di Küfah lebih khusus lagi Sahabat 'Abdullāh b. Mas'ūd (w. 32). Berdasarkan penelitian 'Ali b. b. al-Madini (w. 234) ilmu (Hadis) dari Nabi sampai kepada umat melalui enam orang. Kepada penduduk Mekkah oleh 'Amr b. Dīnar, kepada Madinah oleh Ibn Shihāb al-Zuhrī, kepada penduduk Küfah oleh Abū Ishāàq al-Sabi ‘̄i dan Sulaymān b. Mihrān al-A'mash, kepada Penduduk Bașrah oleh Yahyaa b. Abì Kathīr dan Qatādah. ${ }^{108}$

Secara lebih panjang, Ibn 'Adi dalam al-Kāmil mengutip pernyataan itu melalui Abū Zur'ah al-Rāzì, Hadis orang-orang terpercaya terkonsentrasi pada enam orang. Dua orang di Küfah, dua orang di Bașrah dan dua orang di Ḥijāz. Dua orang di Bașrah adalah Qatādah dan Yahyā b. Abī Kathīr. Dua orang di Kūfah adalah Abū Isḥāq dan al-A'mash. Dua orang di Ḥijāz adalah al-Zuhri dan 'Amr b. Dīnar. Hadis dari enam orang ini kemudian menyebar melalui Sa 'ĩd b. Abī 'Arūbah, Shu'bah b, al-Ḥajjāz, Ma'mar b. Rāshid, Ḥamad b. Salamah, Jarīr b. Hazim dan Hishām al-Dustawā'i di Bașrah. Melalui Sufyān al-Thawrì, Ibn 'Uyainah dan Isrā'il ke Küfah dan melalui Ibn Juraij, Muḥammad b. Isḥāq dan Malik ke Hijāz. Menurut Abū Zur'ah, Hadis ke-12 orang itu menyebar melalui Sufyān b. 'Uyainah. ${ }^{109}$

Melalui dua pernyataan di atas adalah mudah untuk mendeteksi siapa desiminator Hadis di masing-masing wilayah. Dalam kasus penelitian ini, jejaring periwayat Küfah akan kita mulai melalui Abū Isḥaq al-Sabi 'i dan alA'mash. Dari siapa mereka berdua mendapatkan materi Hadis hingga kepada Sahabat sebagai sumber pertamanya, demikian juga sosok Sufyān al-Thawrì, Ibn 'Uyainah dan Israil kepada siapa mereka meriwayatkan Hadis hingga kepada kolektor Hadis (mudawwin). Dengan begitu, akan terlihat jejaring Hadis Küfah dimaksud.

Common Link (CL) dalam istilah G.H.A Juyunboll atau madār dalam istilah Imam Turmudhi dalam penelitian ini ditafsirkan dalam kerangka Harald Motzki. Demikian sebab CL menurut Juyunboll dan lainnya dianggap sebagai pemalsu Hadis, sebaliknya, sementara menurut yang terakhir

107 Christopher Melchert, "How Hanafism Came to Originate in Kufa, 318; Christopher Melchert, "The Early Hanafiyya in Kufa," Journal of Abbasid Studies 1 (2014): 23.

108 'Ali b. al-Madinì, al-'Ilal (Beirut: al-Maktab al-Islāmì, 1980), 36-37.

${ }^{109}$ Ibn ‘Adì, al-Kāmil fi Du 'áfá’ al-Rijāl (Beirut: Dār al-Kutub al-'Ilmiyyah, 1997), 1: 160 . 
dianggap sebagai penyusun dan desiminator Hadis pertama. Bagi penulis, CL Küfah mengikuti pendapat 'A Ii b. al-Madinī (w. 234) adalah sosok al-A'mash (w. 148) dan Abū Isḥāq al-Sabí ‘ (w. 129). Sebuah Hadis yang diriwayatkan oleh keduanya, jika rangkaian periwayat ke atasnya hingga Sahabat Nabi juga berasal dari Küfah, kita akan menganggap Hadis tersebut sebagai Hadis Küfah.

\section{SIMPULAN}

Mendudukkan Hadis dalam konteks ruang dan waktu penting dilakukan agar kontekstualisasi mendapatkan argumentasi ilmiahnya. Hadis tidak muncul secara tiba-tiba dan dalam ruang kosong. Dating hadith adalah usaha akademik bagaimana Hadis sebagai fakta sejarah dipahami oleh masyarakat kekinian. Menanggal Hadis tidak hanya berkepentingan mengetahui kapan sebuah Hadis muncul, lebih dari itu di mana Hadis itu muncul dan menjadi fakta empirik. Studi Hadis kawasan (regionalism), bisa dikembangkan oleh para pengkaji Hadis dalam mamahami Hadis Nabi, baik pada masa periwayatan atau pasca periwayatan. Dengan demikian, Hadis Nabi tidak dianggap barang antik, tidak tersentuh, tapi secara logis meyakinkan untuk dikontekstualisasikan.

\section{DAFTAR PUSTAKA}

al-Madinī, 'Alì b. al-'Ilal. Beirut: al-Maktab al-Islāmì, 1980.

Abū Shuhbah, Muhammad b. Muhammad. al-Wasịt fí 'Ulüm wa-Muștalāh alHadith. Kairo: 'Ālam al-Ma'rifat, t.t.

Adonis. Arkeologi Sejarah Pemikiran Arab Islam. Yogyakarta: LKiS, 2011. al-Dhahabì. al-Amșār Dhawāt al-Âthär. Beirut: Dār ibn Kathīr, 1985. . Mizàn al-I'tidāl fí Naqd al-Rijàl. Beirut: Dār al-Ma'rifat, t.t.

al-Iṣfahānī, Abū Nu'aim. Ma 'rifat al-Saḥābah. t.tp: Dār al-Wațan li al-Nashr, t.t.

al-Kattānì, Muḥammad b. Ja'far. al-Risālah al-Mustatrafah li-Bayān Mashhūr Kutub al-Sunnah al-Musharrafah. Beirut: Dār al-Bashāir al-Islāmiyyah, 1993.

al-Khatīb, Muḥammad 'Ajāj. Aḍ̛̂à' 'alà al-'I'lām fì Sadr al-Islām. Beirut: Mu' assasah al-Risālah, 1985.

al-Mizzì. Tahdhīb al-Kamāl fì Asmā' al-Rijāl. Beirut: Muassasah al-Risālah, 1983.

al-Nasā'ì, Sunan al-Nasa'ī. Beirut: Dār al-Kutub al-'Ilmiyyah, t.th.

al-Rahawān, Mohammad Sa ${ }^{\circ}$ id Mitwally Ibrāhim. "Detecting Textual Additions of Reliable Hadith Transmitters." Islamic Studies 49, 3 (2010). 
al-Samlāii, 'Abd al-Laṭif. "Darr al-Ṣahạābah fiman Dakhala Miṣr min alȘahābah li-Jalāluddin al-Suyūṭ̂i." http://www.oqba.ma/Article.aspx?C=5663. Akses 8/2/2017.

al-Shawkānì. Nail al-Awțār Sharḥ min Asrār Muntaqā al-Akhbār. Kairo: Dār ibn al-Jauzì, 1427.

Amin, Kamaruddin. Menguji Kembali Keakuratan Metode Kritik Hadis. Bandung: Mizan, 2009

Attasi, Aḥmad Nazir. "A History of Ibn Sa'd's Biographical Dictionary Kitāb al-Ṭabaqāt al-Kabīr.": 1.

Azami, MM. Hadis nabawi dan Sejarah Kodifikasinya. Terjemah Ali Mustafa Ya'qub. Jakarta: Pustaka, Firdaus, 2009.

Brown, Jonathan A. C. Hadith: Muhammad's Legacy in the Medieval and Modern World. Oxford: OneWorld, 2009.

Cook, Michael A. "The Opponents of the Writing of Tradition in Early Islam." Arabica 44 (1997).

Crone, Patricia. Roman, Provincial and Islamic Law. Cambridge: Cambridge University Press, 1987.

Donner, Fred M. Narrative of Origins: The Beginnings of Islamic Historical Writing. Princeton: Darwin Press, 1999.

Dudireja, Adis. "Evolution in Canonical Sunni Hadith Body of Literature and Concept of an Authentic Hadith During the Formative Period of Islamic Thought as Based on Recent Western Scholarship." Arab Law Quarterly 23 (2009).

Görke, Andreas. "Prospects and Limits in the Study of the Historical Muhammad." in Nicolet Boekhoff at al,. The Transmision and Dynamics of the textual Sources of Islam: Essays in Honour of Harald Motzki. Leiden: Brill, 2011.

Hamidān, Muntașir Nāfidh Muhammad. "Al-Sunnah baina al-Tashrī' waManhajiyat al-Tahsrī'." Risālah al-Mājistīr, Kuliyyat Dirāsāt al-'Ulya Palestina, 2006.

Hagen, Gotfried. "The Imagined and Historical Muhammad." Journal of the American Oriental Society 129, 1 (2009).

Haider, Najam Iftikhar. "The Geography of Isnād: Possibilities for the Reconstruction of Local Ritual Practice in the 2nd/8th Century." Der Islam 90, 2 (2013).

. "Mu'āwia in the Hijāz: The Study of a Tradition.": 43-55, dalam M. Cook et all, Law and Tradition in Classical Islamic Thought: Studies in Honor of Professor Hossein Modarressi. New York: Palgrave MacMillan, 2013.

Hallaq, Wael B. "The Use and Abuse of Evidence: the Question of Provincial and Roman Influences on Early Islamic Law." Journal of the American Oriental Society Vol. 110, no. 1 (Jan-March, 1990). 
Ibn 'Adì. al-Kāmil fi Du'afă' al-Rijāl. Beirut: Dār al-Kutub al-'Ilmiyyah, 1997.

Jabali, Fu'ad. Sahabat Nabi: Siapa, Kemana dan Bagaimana. Bandung: Mizan, 2010.

. The Companions of the Prophet: A Study of Geographical Distribution and Political Alignments. Leiden: Brill, 2003.

Juynboll, G.H.A. Muslim Tradition: Studies in Chronology, Provenance and Authorship of Early Hadith. Cambridge: Cambridge University Press, 1983.

Khaḍr, Ozjān. "Manāhij al-Mustashriqin fî Tārikh al-Ahāođith." Majallah alMuslim al-Mu'āsirir 32.

Kizil, Fatma "Fazlur Rahman's Understanding of the Sunnah/Hadith: A Comparison with Joseph Schact's View on Subject." Hadis Tetkikleri Dergisi VI/II (2009).

Kuzudisli, Bekir. "Hadith of Man Kadhaba 'alayya and Argumentum e silentio." Hadith tetkileri Dergisi (TTD).

Lucas, Scott Cameron. "The Arts of Hadith Compilation and Criticism: A Study of Emergence of Sunnism in the Third/Ninth Century." Ph.D Dissertation of Department of Near Eastern Languages and Civilizations Chicago University, 2002.

Mahmudah, Nur. "Pemikiran G. H. A Juynboll tentang Hadis." Mutawatir: Jurnal Keilmuan Tafsir-Hadis Volume 3, Nomor 1 (Juni 2013).

Maghen, Ze'ev. “Joseph Schacht and the Origins of Popular Practice." Islamic Law and Society 10, 3 (2003).

Melchert, Christopher. "How Hanafism Came to Originate in Kufa and Traditionalism in Medina." Islamic Law and Society (1999).

Minhaji, Akh. Islamic LaW and Local Tradition: A Socio-Historical Approach. Yogyakarta: Kurnia Alam Semesta, 2008.

. "Joseph Schacht's Contribution to the Study of Islamic Law." MA Thesis Institut of Islamic Studies McGill University Canada.

Motzki, Harald. "Dating Muslim Tradition: A Survey," Arabica (2005). "The Musannaf of Abdul Razzāq al-Șan'āni as A Source of Authentic Ahādith in the First Century." Journal of the Near Eastern Studies 50 (1990).

"Whither Hadith Studies?." in Analysing Muslim Tradition: Studies in Legal, Exegetical and Maghāzi Hadith. Leiden: Bill, 2010.

Mūsa, Muhammad al-Thānī 'Umar. al-Madrasah al-Hadithiyyah fì Makkah wa Atharuhā fì al-Hadith wa 'Ulümih min Nash'atihà hattā Nihàyah alQarn al-Thānī al-Hijrī. Riyāḍ: Maktabah Dār al-Minhāj, 1428.

Rahman, Fazlur. Membuka Pintu Ijtihad. Bandung: Pustaka, 1983.

Rakhmat, Jalaludin. Misteri Wasiat Nabi, Asal-usul Sunah Sahabat: Studi Historiografi atas Tarikh Tasyri'. Bandung: Misykat, 2015. 
Sadeghi, Behnam. "The Traveling Tradition Test: A Method for Dating Tradition," Der Islam, Bd. 85 (2010).

Schacht, Joseph. "The School of Law and Later Development of Jurisprudence." Law in the Middle East. . The Origins of Muhammadan Jurisprudence. Oxford: The Clarendon Press, 1975. . Introduction to Islamic Law. Oxford: Clarendon Paperback, 1964.

Schoeler, Gregor. "The Constitution of Koran as a Codified Work: Paradigm for Codifying Hadith and the Islamic Sciences." Oral Tradition 25/1 (2010).

Schoeler, Gregor. "Foundation for a New Biography of Muhammad: The Production and Evaluation of the Corpus of the Tradition According to 'Urwah ibn al-Zubayr." in Herbert Berg (ed)., Method and Theory in the Study of Islamic Origins. Leiden: Brill, 2003.

Shaukat, Jamila. "Clasification of Hadith Literature." Islamic Studies Vol. 24, No. 3 (1985).

Shoemaker, Stephen J. "In Seacrh of Urwa's Sira: Some Methodological Issues in the Quest for the Authenticity in the Life of Muhammad." Der Islam 85 (2011).

Stodolsky, Volkan Yildiran. "A New Historical Model and Periodization for the Perception of the Sunna of the Prophet and his Companions." Ph.D Dissertation of Department of Near Eastern Languages and Civilizations, Chicago University, 2012.

Vikor, Knut S. "The Origins of the Sharia." Dalam Rudolp Peters \& Peri Bearman (ed), The Asghate Research Companion to Islamic Law. London: Routledge, 2014.

Wakin, Jeanete. "Remembering Joseph Schacht (1902-1906)." Ocassional Publication 4 (2003).

Zaman, Muḥammad Qasim. "Maghāzī and Muhaddithūn: Reconsidering the Treatment of Historical Materials in Early Collections of Hadith.“ International Journal of Middle East Studies Vol 28, No. 1 (1996). 